\title{
Contemporary practices in groundwater arsenic remediation and wastewater management in West Bengal, India: a systematic review
}

\author{
Soumyajit Kole ${ }^{*}$ \\ Department of Civil Engineering, Indian Institute of Technology, Kanpur, Kalyanpur - 208016, UP, India
}

Received: 22-June-2021; Revised: 26-July-2021; Accepted: 27-July-2021

(C)2021 Soumy ajit Koley This is an open access article distributed under the Creative Commons Attribution (CC BY) License, which permits unrestricted use, distribution, and reproduction in any medium, provided the original work is properly cited.

\begin{abstract}
Arsenic is a notorious carcinogen that is released into subsurface waters by virtue of natural geological and hydrological processes. Such a contaminated water has detrimental effects on human health when it is consumed for drinking. This paper is an effort to address the widely recognized public health crisis of arsenic poisoning in India's state of West Bengal. It is intended to provide an environmentally safe and financially feasible solution for arsenic mitigation that combines both ground water remediation and waste management situations. Treatment of pumped groundwater by Arsenic Treatment Units (ATUs) for providing potable water has been a major arsenic remediation measure in rural villages of West Bengal. But, backwash cleaning of these units generates hazardous sludge rich in toxic arsenic, disposal of which is an environmental concern. Through a field examination, detailed information on the prevalent sludge management practices at remote ATU sites were acquired and reviewed for their suitability. It was ascertained that wrongful dumping of sludge can be avoided by disposal on certain iron-rich sand filters, constructed in-situ using naturally available ingredients. Also, the incorporation of sludge in building materials, especially the clay-bricks, can be an emphatic option for arsenic waste management at commercial scales. This paper thus presents a comprehensive overview of 'in-situ' and 'ex-situ' strategies of arsenic mitigation. An 'in-situ' management aspect utilizes iron-rich sand filters located within the premises of groundwater treatment units for recycling of arsenic-containing wastewater, followed by adsorption and concealment of residual arsenic. An alternative, hazard-free means of stabilizing toxic sludge off-site, with clay-bricks, at a brick manufacturing factory, has been proposed for the 'ex-situ' aspect. Many policy discussions around the globe do not feature arsenic-sludge disposal or stabilization as a topic. Keeping this is viewed, this review article concludes with innovative approaches to sustainable arsenic remediation and waste management in India.
\end{abstract}

\section{Keywords}

Arsenic, Groundwater, Treatment, Sludge, Sand filter, Bricks.

\section{Introduction}

Globally, intrusion of toxic heavy metals into groundwater ecosystems has been a topic of serious concern for sustaining public health. Extracting contaminated subsurface waters for consumption as drinking water intake has led to catastrophic debilitations in populations, particularly those in rural areas of developing countries lacking robust municipal water-supply infrastructures [1]. Within this subject matter, mysterious and rampant geochemical release of arsenic in the subsurface waters of India (as depicted in Figure 1(a)) has impaired the concerted mitigation efforts of several geologists and environmental science researchers around the world. Arsenic (As) is a notorious carcinogen and its chronic intake causes incurable health problems [2, 3].

\footnotetext{
*Author for correspondence
}

It is a metalloid which occurs naturally in different inorganic and organic forms.

The estimated abundance of arsenic in the earth's upper crust is in excess of $1.5 \mathrm{ppm}[4,5]$. It is colourless, odourless and tasteless when dis solved in water, and thus cannot be detected easily by simple observation [6]. Factors like water temperatures, $\mathrm{pH}$ and salinity, oxidation state, etc. control the speciation, mobilization and fate of arsenic in water [7, 8]. Arsenic goes through a series of modifications by redox reactions, ligand changes and biotransformations within a $\mathrm{pH}$ range of $6.5-8.5$ that is typically found in shallow aquifers [9-11].

In the subsurface environments, it occurs largely in its inorganic form, which has been classified as a severe human carcinogen $[12,13]$. As little as 70 to $180 \mathrm{ppm}$ of arsenic poisoning in the human body can be fatal, 
notably for women [14-16]. Arsenic in drinking water is not allowed to exceed $0.01 \mathrm{mg} / \mathrm{L}$ according to the guideline from the World Health Organization (WHO) [17]. Yet, the drinking water in countless rural habitations of South Asia contains arsenic poisoning. Groundwater arsenic contamination in the Bengal Delta Plain, which constitutes Bangladesh and the Indian state of West Bengal, has been a globally known natural catas trophe for over three decades. The geogenic nature of arsenic release in Indo-Gangetic aquifers has been mostly attributed to fluvial sediments originated from the Himalayas [18-20], with pervasion caused due to its mobilization under natural hydro-geological conditions [21-23]. This predicament has been assessed to be the biggest, and the most relentless, case of groundwater arsenic contamination in the planet $[24,25]$.

India's West Bengal is one of the critically affected regions in this regard. Figure 1(b) expresses the extent of this crisis in the region. Six districts in the state, namely Murshidabad, Maldah, Hooghly, North 24 Parganas, Nadia and South 24 Parganas are adversely affected, where over 100 million people consume water drawn from the shallow aquifers bearing gravely high levels of arsenic. The depth of these contaminated aquifers ranges from 15 to $70 \mathrm{~m}$ below ground level. Several remedial actions have been put to practice by the state government and various other NonGovernmental Organizations (NGOs) to provide potable water to the people living in these regions. These measures predominantly involve tapping and treating river water (Figures 2(a) and 2(b)) and openly-harvested rainwater (Figure 3 ) for supplying potable water to households via piped-water-supply networks [26].

However, establishment and maintenance of the infrastructure required for such networks are not possible in many remote rural villages due to economic and geographical hurdles. As a result, in these areas, hand-pump-fitted tubewells (Figure 4) drawing shallow groundwater remain the primordial source of drinking water, for their easy installation, and availability of the subsurface water for extraction [27, 28]. Hence, arsenic remediation of the extracted groundwater by Arsenic Treatment Units (ATUs) has become indispensable in bringing urgent relief to the arsenic-affected rural habitations [29].
Over the last few years, thousands of ATUs (as in Figure 5) have been set up in the arsenic-affected districts, especially in the remote rural villages. Alongside treatment for other major inorganic contaminants (e.g., iron, fluoride, nickel, barium, etc.), the groundwater being mostly pathogen-free in the region, requires much less disinfection compared to that for the river water, in order to become potable (i.e., safe for drinking). But undesirably, the ATUs generate enormous quantities of wastewater that are rich in toxic arsenic. Arsenic is very mobile and can readily leach if the arsenic-bearing sludge is not stabilized [30]. Exhausted treatment media of these units are not significantly hazardous in this context [31].

But the wastewater needs to be quarantined or disposed in an environmentally safe manner to prevent further contamination of soil and groundwater. A field survey of certain notable ATUs was undertaken by the author, and the ongoing waste management practices were noted. Small-scale ATUs that serve about 600 households for supplying potable water are called Arsenic Removal Units (ARUs), whereas large-scale ATUs that serve more households are commonly termed as Arsenic Removal Plants (ARPs) [1]. In a vigorous attempt to present a technical overview of logical viewpoints of theory and practice in arsenic mitigation strategies, with regards to the ARPs and ARUs, this paper explores the sustainability of such policy initiatives in India.

This article is founded on the author's opinion and perspectives of the status quo of groundwater remediation and wastewater management in India, which has been attained via the extensive field investigations of remote rural habitations in the country. Thematically aimed at achieving the global and regional Sustainable Development Goals (SDGs). This review paper primarily incorporates three key issues of sustainable water and wastewater management policies, namely, (1) Water infrastructure and distribution, and environmental stability, (2) Sludge treatment, including processing, storage and management, (3) Resource remediation, innovations and economic recovery, (4) Decentralized water supply and stakeholder awareness, and (5) Social resilience and development. All the acronyms introduced in this article have been listed as an Appendix I mentioned at the end of this paper. 
International Journal of Advanced Technology and Engineering Exploration, Vol 8(80)

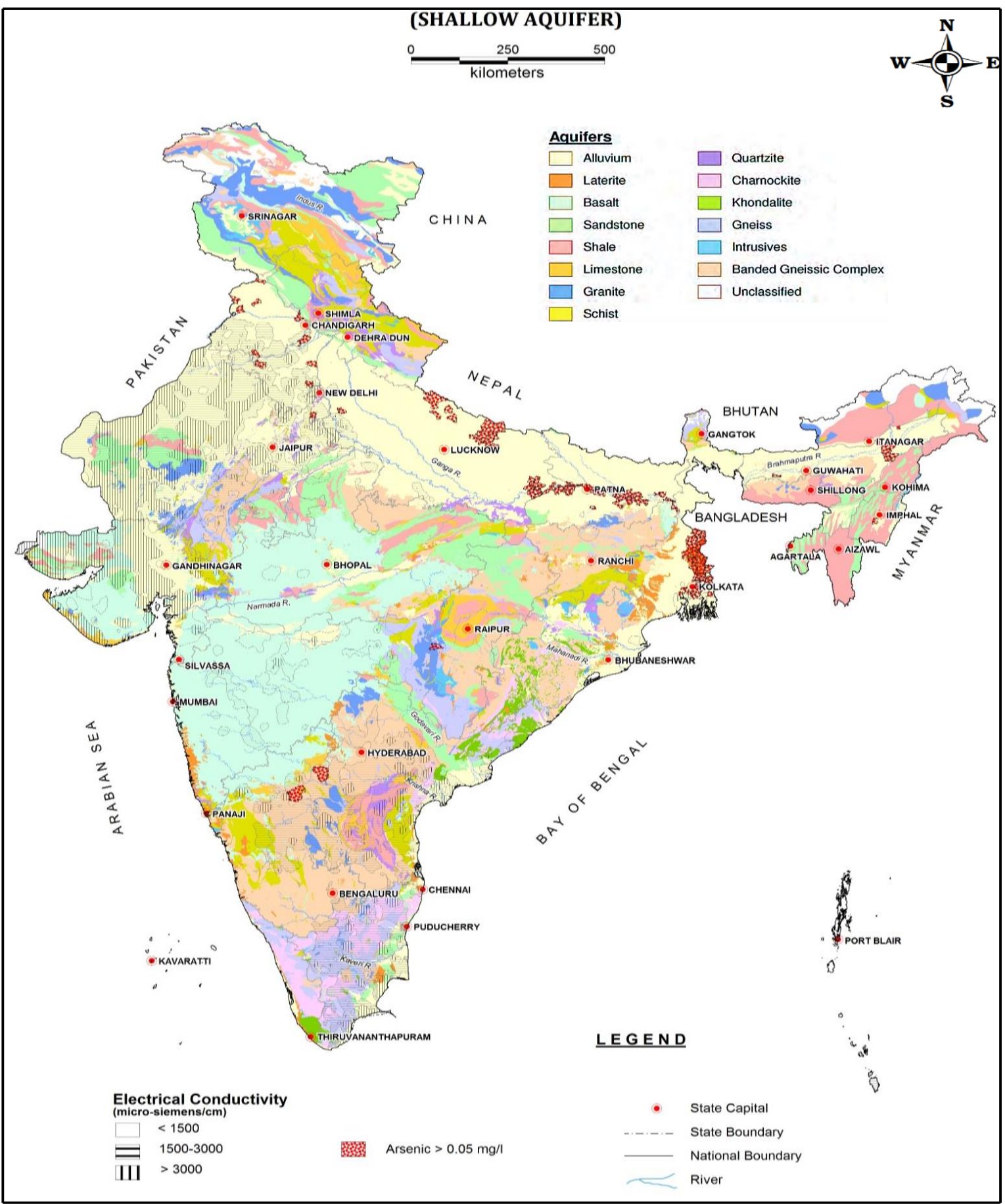

Figure 1(a) Geochemical extent of groundwater arsenic contamination in India (adopted from Koley, 2021 [1] with permission of the copyright owner) 


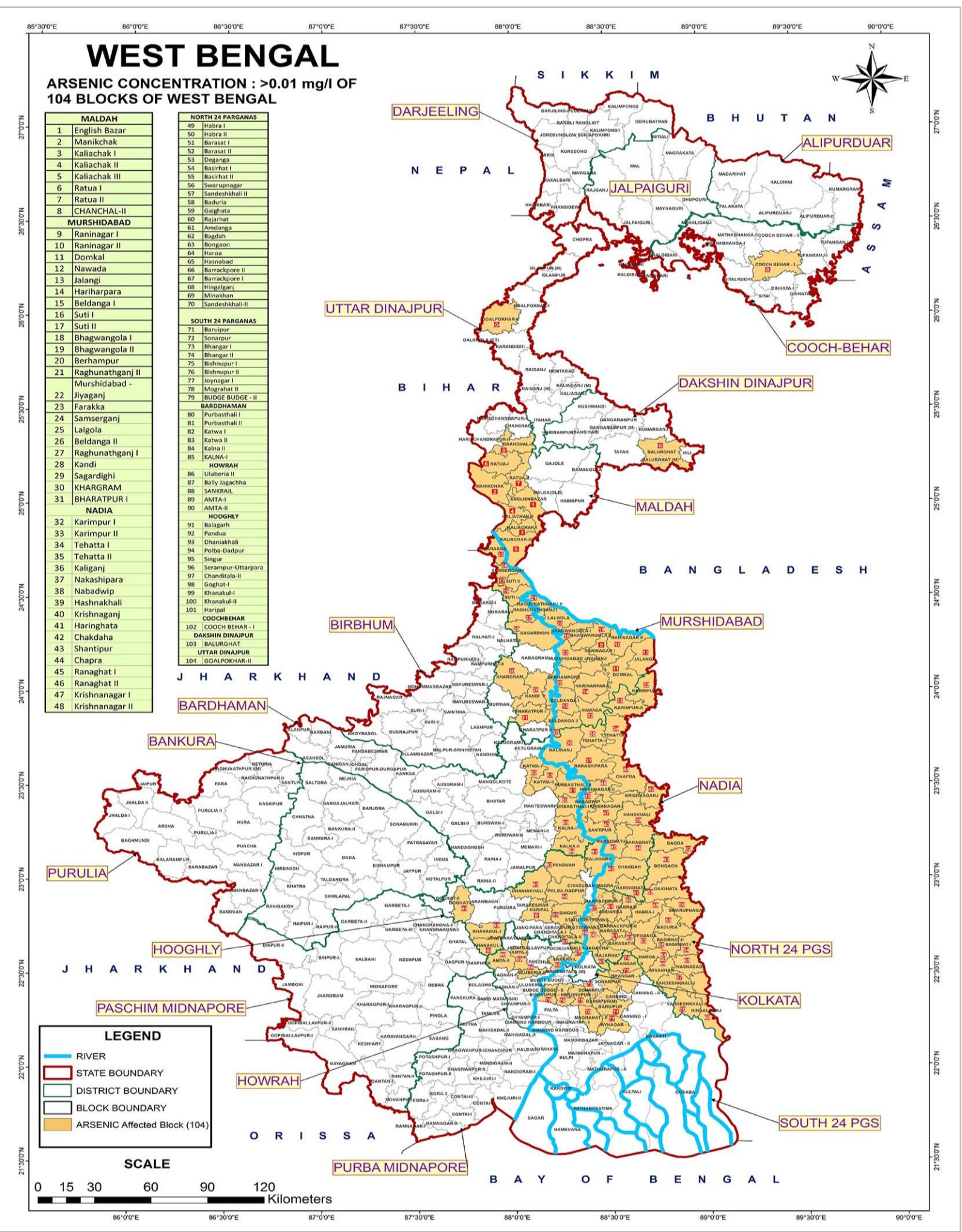

Figure 1(b) Groundwater arsenic contamination situation in the state of West Bengal in India (adopted from Koley, 2021 [1] with permission of the copyright owner) 

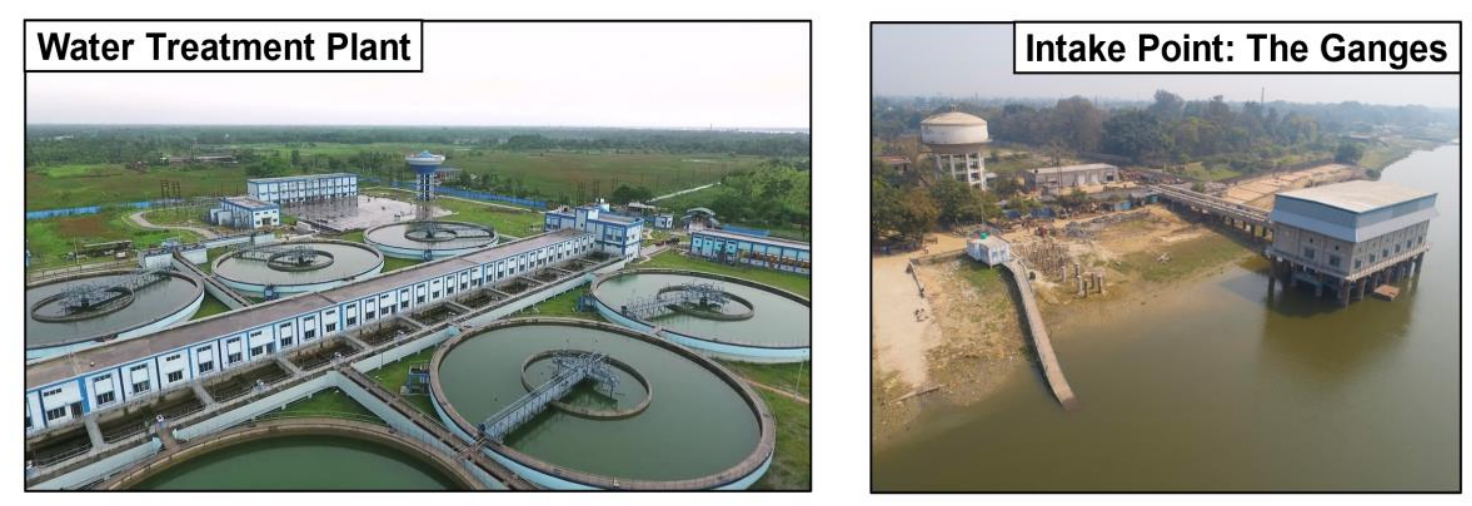

Figure 2(a) Treatment plant of a mega surface water-based water-supply scheme (Falta-Mathurapur) in district South 24 Parganas, West Bengal. Arsenic-free surface water of the perennial river Ganges is abstracted for Piped-WaterSupply Schemes (PWS)
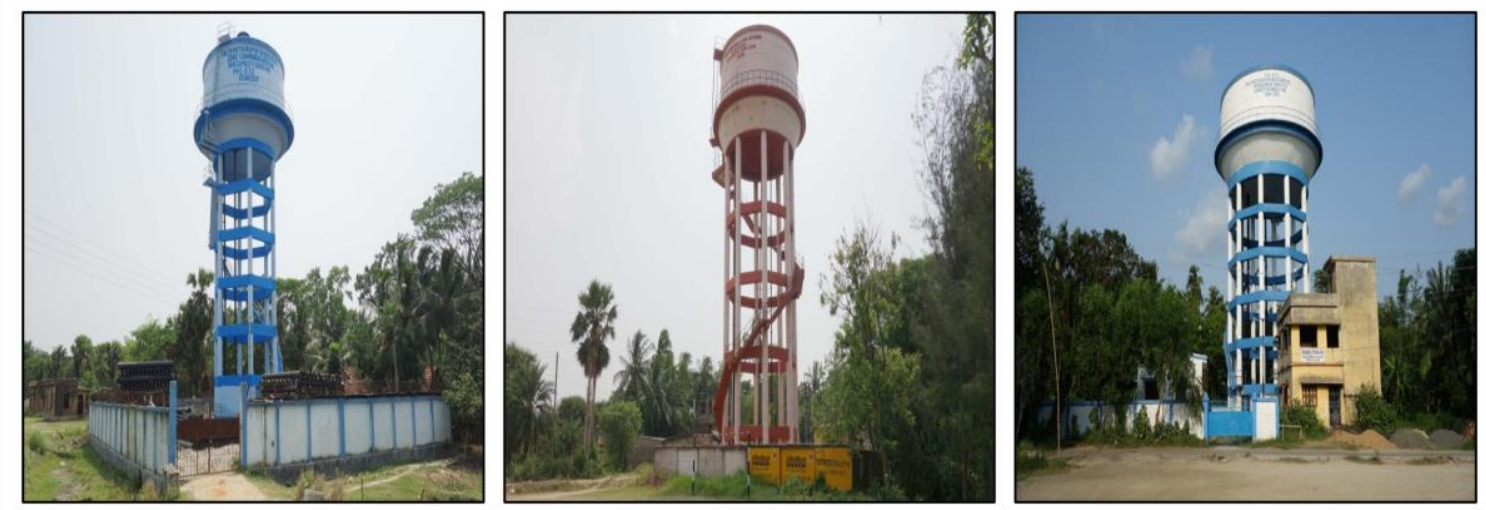

Figure 2(b) Overhead reservoirs to distribute treated surface water to thousands of households via piped-networks. Administrative names, from left to right: Diamond Harbour I (Zone-2), Diamond Harbour II (Zone-6), Uttar Raipur Budge Budge I
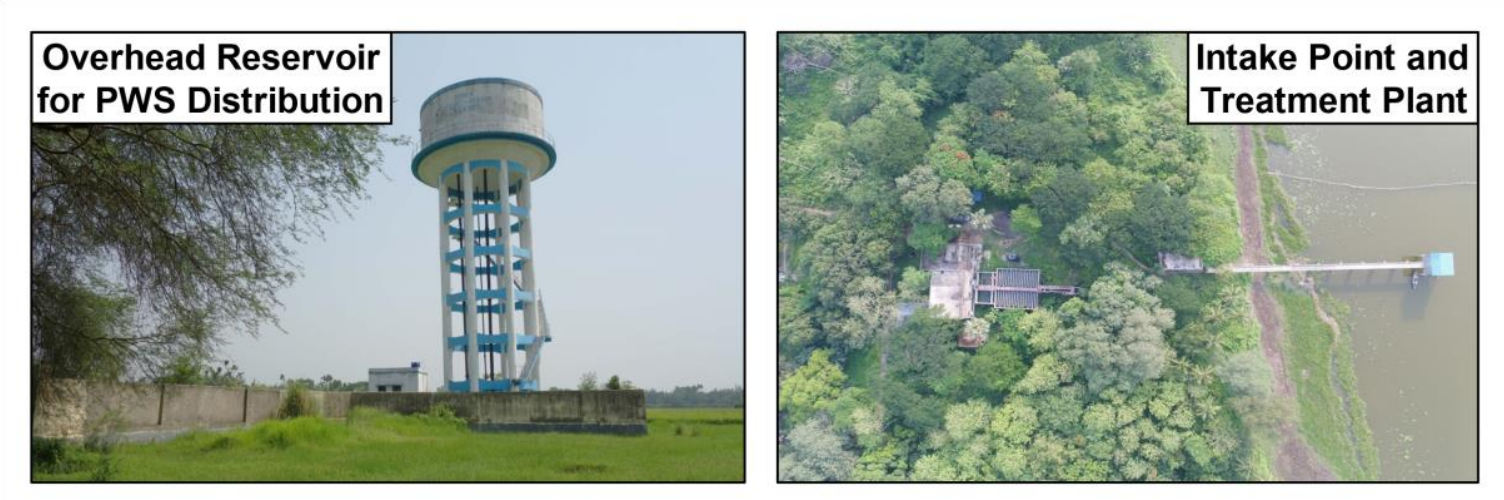

Figure 3 Pond-based rainwater harvesting, water supply scheme in district North 24 Parganas, West Bengal 


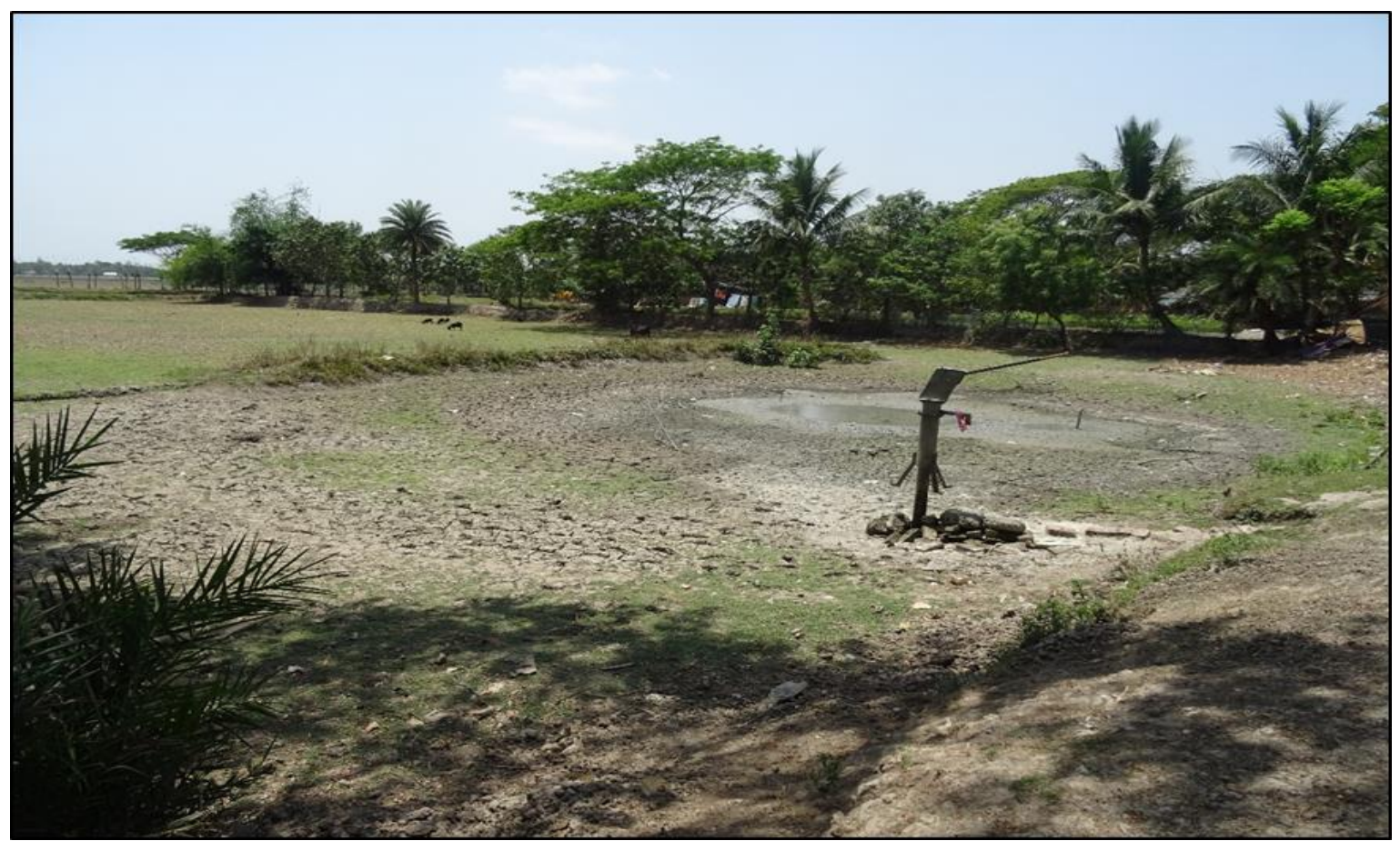

Figure 4 A typical hand-pump-fitted tubewell in rural West Bengal, that has now been abandoned after detection of arsenic in groundwater

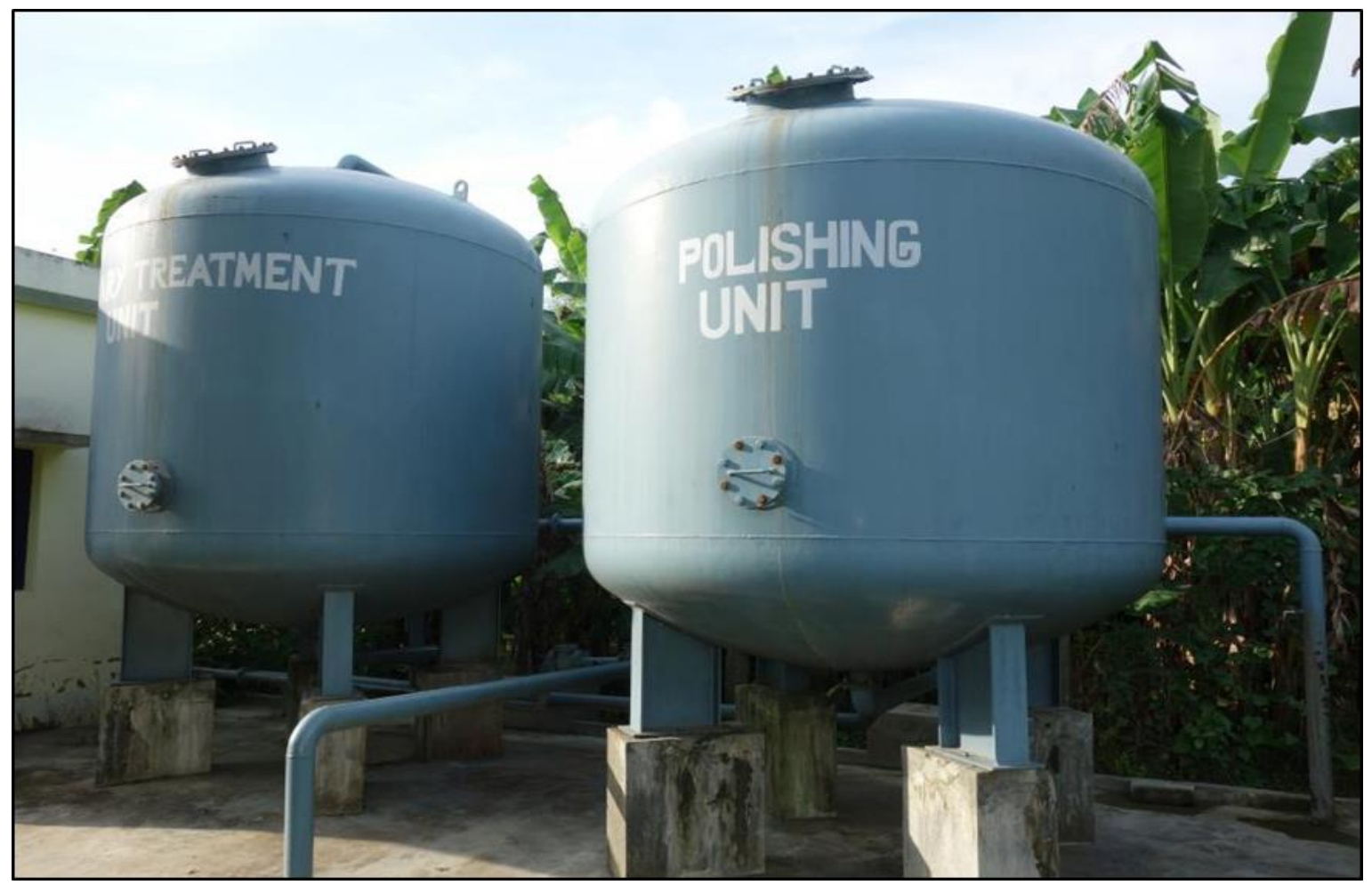

Figure 5 A typical ATU located in doctor para habitation of the Khanjepur village under Tehatta-I block in district nadia, commissioned scheme under Khanjepur water supply scheme 


\section{Crisis situation in India and remedial measures: An overview of literature}

The Bengal Delta plain of India and Bangladesh in Southeast Asia is one of the major arsenic contaminated regions globally. Various hydrochemical studies carried out in the Ganga-MeghnaBrahmaputra (GMB) river basin reveal the provenience of arsenic to be of geogenic inception [32, 33 , that perpetuates and exacerbates spontaneously under natal hydro-geological processes [34, 35]. Oxidation and reduction hypotheses are the most discussed theories to explain the genesis of arsenic mobilization in the subsurface of the GMB basin, with the latter acquiring more scientific acceptance in academia [36-39]. As per the oxidation hypothesis, arsenic is propelled by the oxidation of arsenicbearing sulfide minerals, like Arsenopyrite (FeAsS), in the shallow aquifers, owing to the drawdown induced by groundwater rampant abstraction from the aquifer [40-43].

In the reduction hypothesis, arsenic is thought to be released through dissolution of $\mathrm{Fe} / \mathrm{Mn}$ oxyhydroxides (that are coated on mineral grains in arsenic-bearing sediments) in a reducing environment [44-50]. The groundwater arsenic contamination is widespread in Indian states along the GMB basin, particularly Bihar, Uttar Pradesh, Jharkhand, West Bengal, Assam and Manipur [51-55]. As a result, over 500 million people living in these states have been poisoned by arsenic from drinking water sourced from the aquifers [24, 25, 56, 57].

In the GMB basin, mainly shallow alluvial aquifers (i.e., 15 to 70 meters below ground level) comprise late Quaternary sediments of Holocene age that contain arsenic [19, 21, 58]. In addition to organic matter, the sediment consists of micaceous sand, slits, and clay, which are transported from the Himalayas by the Ganges and its tributaries $[25,59,60]$. The mineralogical composition of these sediments includes mostly feldspar, quartz, kaolinite and illite [18, 49]. Figure 6 shows the Hydrogeology of the state of West
Bengal in India, where the arsenic calamity is widespread. Since the emergence of this geogenic disaster, numerous attempts have been made to model and estimate the fate of arsenic transport in groundwaters [43, 61-63]. But there are uncertainties involved in the findings $[64,65]$.

Artificially recharging an arseniferous aquifer by rain water or surface water [66, 67], or injecting oxygenated water [68, 69], have been found to drastically dilute and reduce the As(III) concentrations in the aquifers. But such a contamination regulation technique does not give much success, because of inadequate understanding of all the ecohydrological processes which govern the geochemical behaviour of these aquifer systems [28, 70].

Nevertheless, a multidimensional programme has been initiated for arsenic mitigation in India's West Bengal with projects ranging from establishment of surface water based piped-water-supply schemes (PWS, as shown in Figure 2(a) and Figure 3) to commissioning of ATUs for supplying potable water to the population in the arsenic-affected zones. Many of these government projects are supervised and funded by international agencies like United Nations Children's Emergency Fund (UNICEF), WHO, World Bank, etc. Resorting to arsenic-free river water of the Ganges for the PWS (i.e. upon suitable chemical and biological treatment) is accepted as the ideal scheme to control the arsenic menace, specifically in the districts where such arrangements can be made possible and beneficial to the society [29].

However, remote rural habitations having no or little access to the surface water based PWS have no other option but to rely on hand-pump-fitted tubewells alone for domestic consumption, particularly in drinking and cooking [71, 72]. Hence, treatment of the extracted groundwater by appropriate ATUs is a vital policy measure for arsenic mitigation in such regions $[28,73]$. 


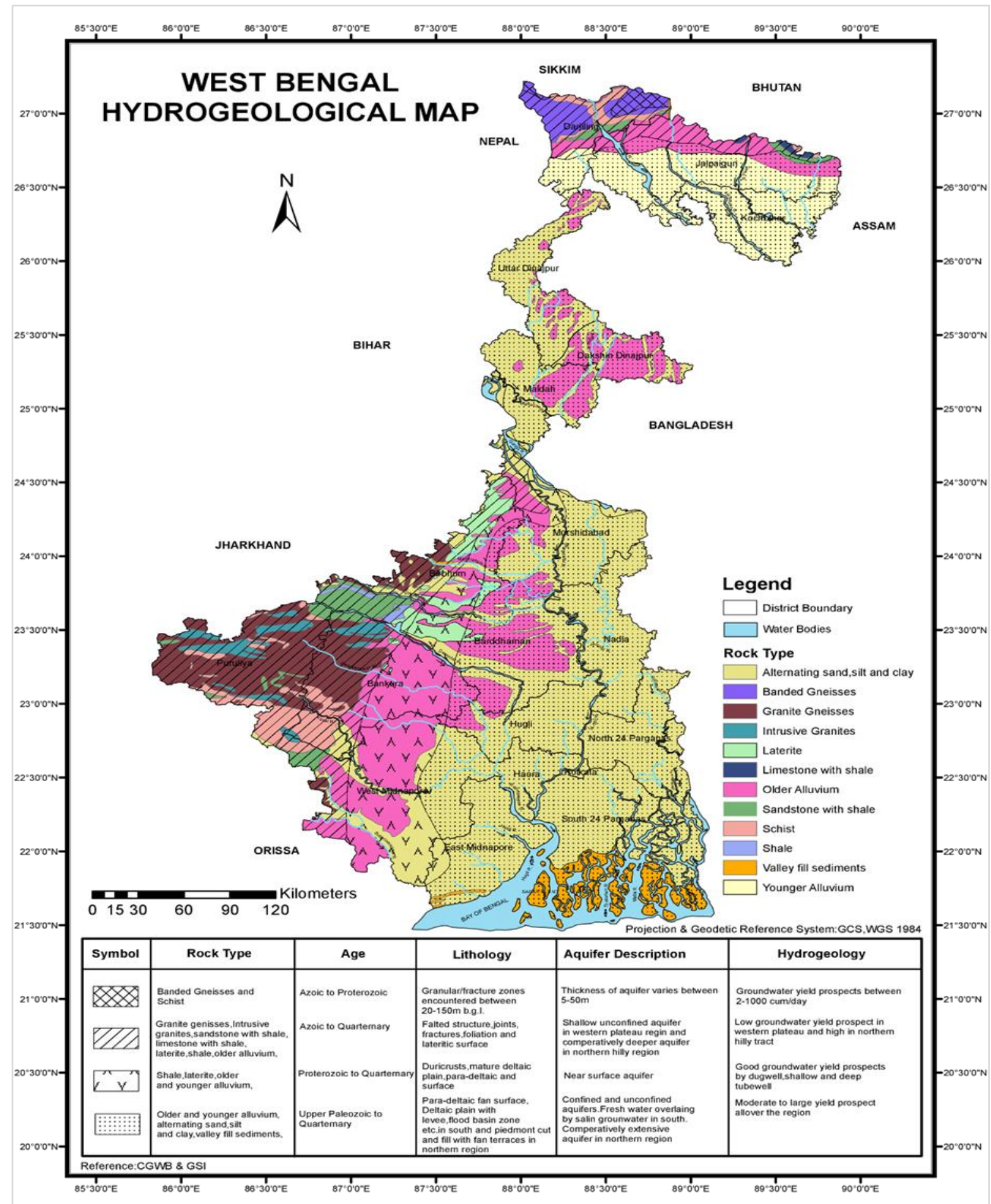

Figure 6 Map showing Hydrogeology of West Bengal, India 


\section{Arsenic treatment units: costs involved and wastes produced}

ATUs are often classified as ARPs (Figure 7, operated $5 \mathrm{~h} / \mathrm{d}$ ) or community-based handpump-tubewellattached ARUs (Figure 8, operated $6 \mathrm{~h} / \mathrm{d}$ ). A typical household in the rural regions of India comprises four members, each of whom consume about $5 \mathrm{~L}$ of water daily in drinking and cooking [74, 75]. Generally, an ARU serves up to 600 hous eholds on a daily basis by providing potable water either on-site, or through water tankers (Figure 9). For convenience in procurement by some distant households, water is delivered by means of commonly available $20 \mathrm{~L}$ reusable Polyethylene Terephthalate (PET) bottles (Figure 10). Usually, mini-trucks like tempos are hired, each having a carrying capacity of 50 PET bottles at minimum, for fast and reliable door-to-door delivery to the distant households. Large-scale ATUs, i.e. the ARPs, serve further more number of households via piped-networks. Operation, maintenance and quality-checks of the units are done by community-clubs composed of trained village personnel employed by government authorities and NGOs. Water tariff to a household ranges from INR $10-20 / \mathrm{L}$ in this regard. Social acceptance and sustainability of an ATU depends on several factors such as the arsenic removal rate and efficiency, the water tariff charges, and user-friendliness in the operation and maintenance (O\&M) [76]. Table 1 shows information on costs and water treatment efficacies of certain ATUs (i.e., ARPs and ARUs) which the author identified in field visits to Nadia and North 24 Parganas districts of West Bengal. These ATUs are run on a non-profit basis and have been found to be widely adopted by rural habitations [77]. On an average, the capital and O\&M costs of an ATU are INR 67,000 (USD 931) and INR 22,000 (USD 306) respectively. Number of ATUs necessary for installation are dependent mainly upon the number of people in an area that remains at high risk of arsenic exposure via drinking water. For keeping the total arsenic concentration limit at $0.01 \mathrm{mg} / \mathrm{L}$ in treating drinking water [31], the ATUs follows the Indian standard specification IS 10500: 2012, while also allowing a maximum limit of $0.05 \mathrm{mg} / \mathrm{L}$ in the absence of alternative drinking water sources in the region under consideration [78]. If the maximum permissible limit of arsenic in treated drinking water of the ATUs is strictly enforced to be $0.01 \mathrm{mg} / \mathrm{L}$ based on United States Environmental Protection Agency (USEPA's) revised rule, more expenses would be required for the establishment of the upgraded ATUs in this context. This would result in an increased remediation cost of the groundwater [79].

805
Technologies to treat arsenic in pumped groundwater principally include oxidation, adsorption or coagulation of arsenic, followed by separation of the residue thus produced via filtration [80, 81]. In general, iron, aluminium and their minerals are as used as water treatment media in the ATUs, in view of their high co-precipitation and sorption affinity towards arsenic [82, 83]. Some ATUs utilize manganese greensand in combination to enhance the treatment efficiency [84]. The media are typically designed in a way to have ample sorption sites in effectively adsorbing arsenic despite the presence of other competing oxyanions in the groundwater, such as carbonate $\left(\mathrm{CO}_{3}-\right)$, sulphate $\left(\mathrm{SO}_{4}{ }^{2}-\right)$, nitrate $\left(\mathrm{NO}_{3}-\right)$, silicate $\left(\mathrm{H}_{2} \mathrm{SiO}_{4}{ }^{2-}\right)$, phosphate $\left(\mathrm{H}_{2} \mathrm{PO}_{4}{ }^{-}\right)$, etc. They also remove other water contaminants like fluoride, lead, barium, chromium, etc. With up to $0.5 \mathrm{mg} / \mathrm{L}$ of arsenic in the contaminated feed water, the ATUs often remove more than $90 \%$ of the arsenic. However, presence of particulate matter in the feed water and deposition of arsenic-iron precipitates on filter media formed during the treatment of water by adsorption or coagulation, plug the media over time which leads to increasing head loss and reduction in hydraulic capacity of the units. In order to avoid clogging of the media and restore its optimal water treatment efficiency, the system requires periodical cleaning by backwashing. The treatment sludge (of about $1 \mathrm{~g} / \mathrm{cm} 3$ bulk density) thus removed as waste from these units, either in the form of slurry (from co-precipitation based ATUs, as in Figure 10) or brine wastewater (from adsorption or ion exchange based ATUs, as in Figure 11(a)), are generally voluminous and encompass high concentrations of arsenic toxicity [85]. Annually, about $550 \mathrm{~L}$ of wet sludge is generated from backwash cleaning of an ARU alone [86]. Solid wastes are essentially the spent media, which get enervated over time by arsenic adsorption (Figures $12(a)$ and $12(b))$. Recovery of arsenic by its desorption from the spent media can be achieved with acid and alkaline washing (i.e., by using dilute $\mathrm{H}_{2} \mathrm{SO}_{4}$ and $\mathrm{NaOH}$ respectively) at $20-40{ }^{\circ} \mathrm{C}$ temperature range, and it has been noted that low temperatures facilitate the desorption process $[87,88]$. This procedure not only helps in recovering the adsorbed arsenic, but also regenerates the media for a further reuse. Exhausted treatment media of adsorption-based units are generally regenerated 3-4 times before being replaced or recharged by new ones $[31,89,120,125,126]$. Lately, some pilot studies have been conducted in developing simplistic, robust and affordable arsenic remediation methods using electro-coagulation techniques, which do not require a treatment media or much use of chemicals, and thus produce extremely 
low quantities of sludge [90-93]. The techniques make use of electrolytic oxidation of ordinary mild steel electrodes in the contaminated water by passing direct current at a suitable voltage to produce iron oxyhydroxides, which co-precipitate with arsenic to form flocs that can then be separated by filtration. While efforts are currently underway in developing scalable business models for sustainable implementation of such techniques at electrified villages, successful operation of the existing ATUs and associated waste handling methods continue to remain a difficult task.

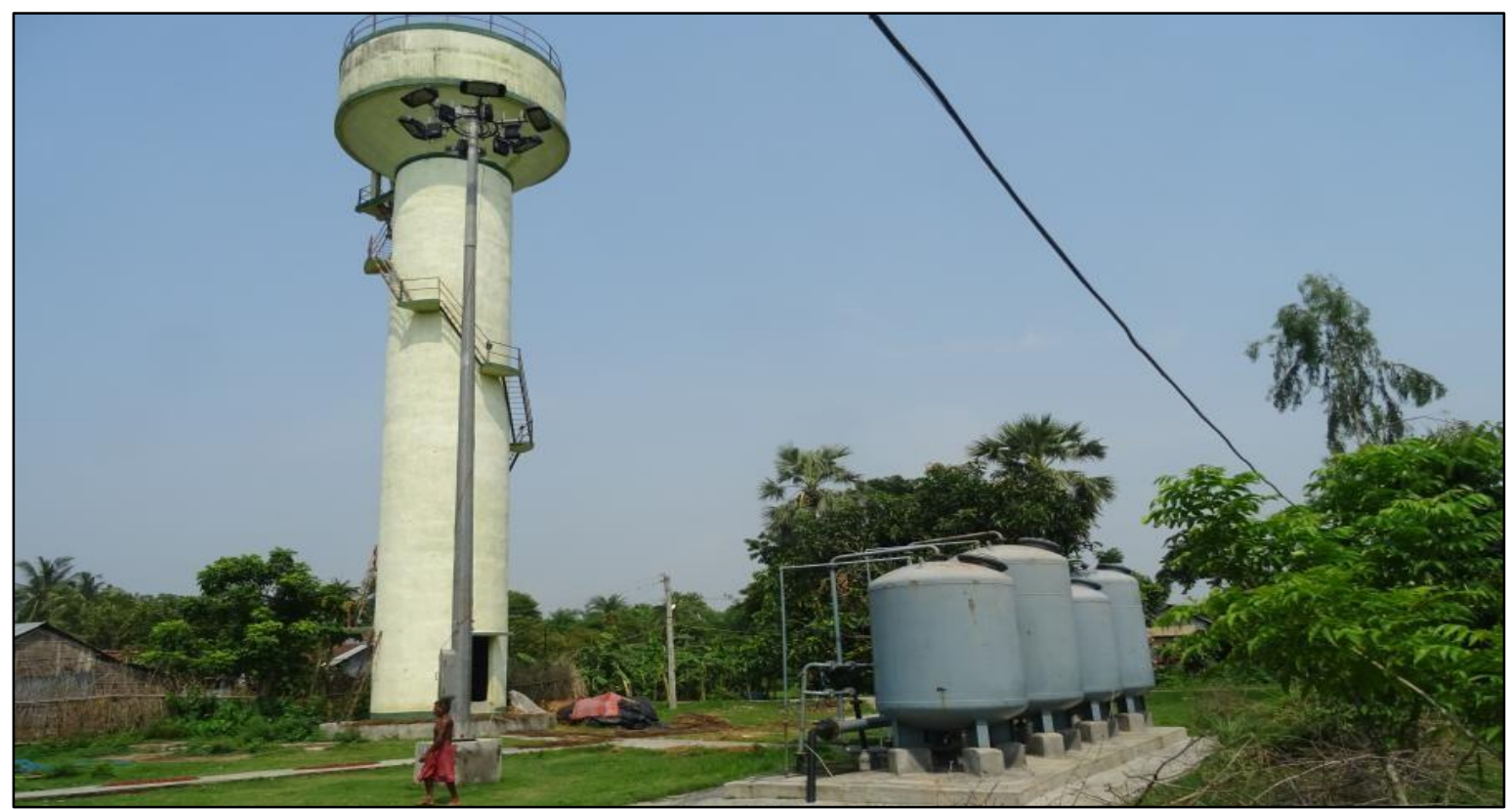

Figure 7 A typical ARP located in Char Panpara habitation of Panpara village under Shantipur block in district Nadia, commissioned scheme under Gayes pur Water Supply Scheme (Zone-2)

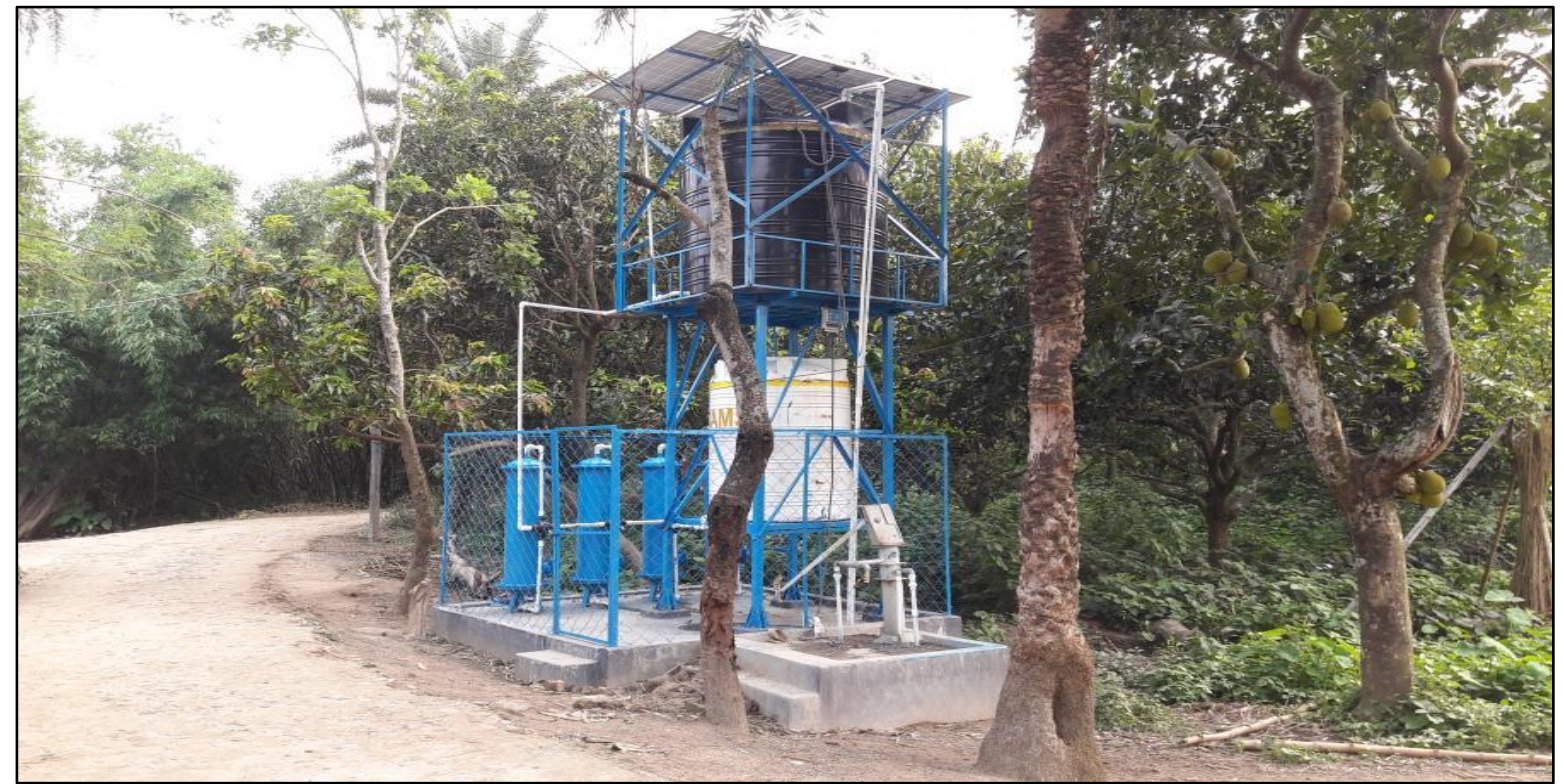

Figure 8 A typical ARU located in the Tajpur habitation of Uttar Tajpur village under Karimpur-I block (GP Pipul Baria) in district Nadia 


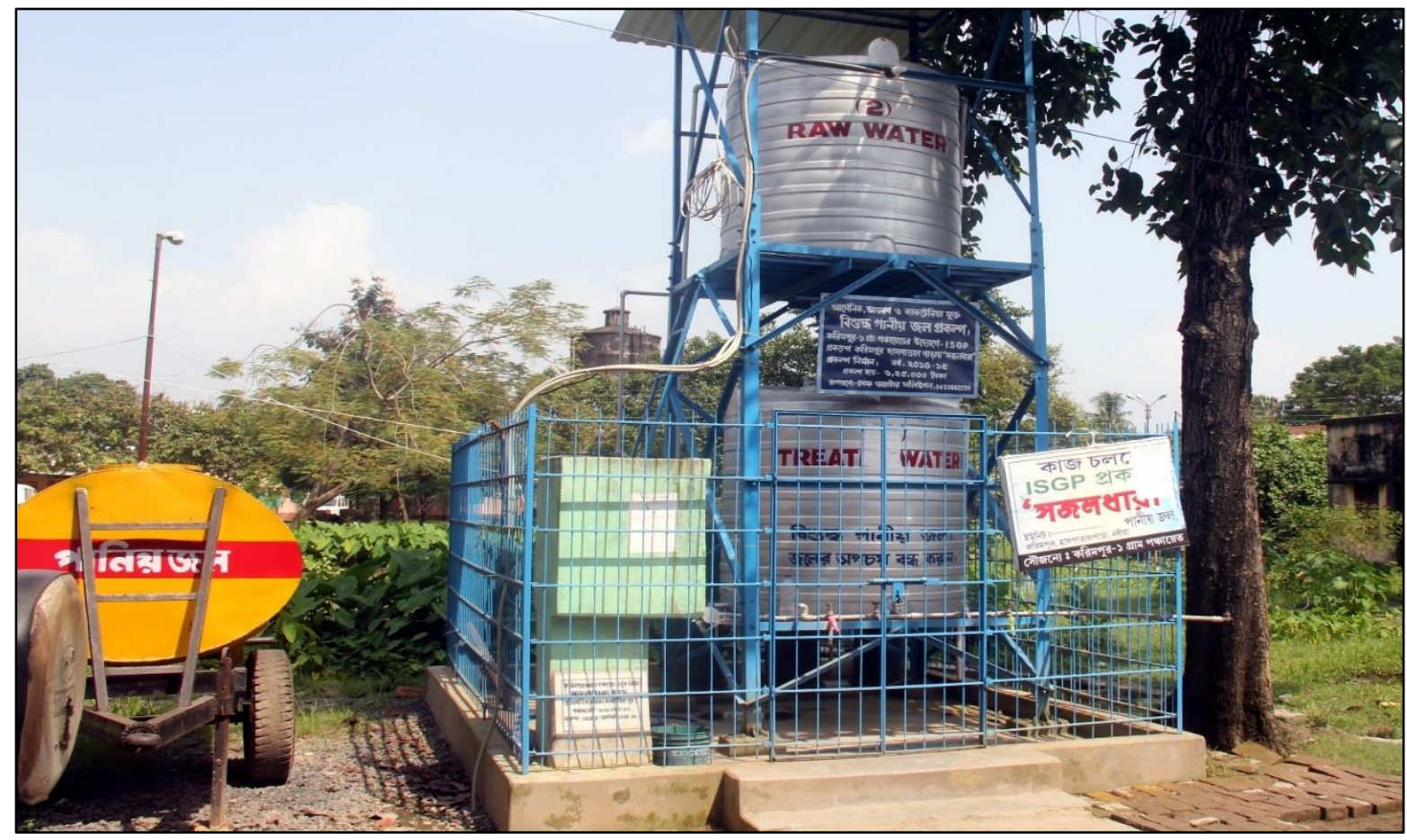

Figure 9 Water tanker to supply drinking water to distant households

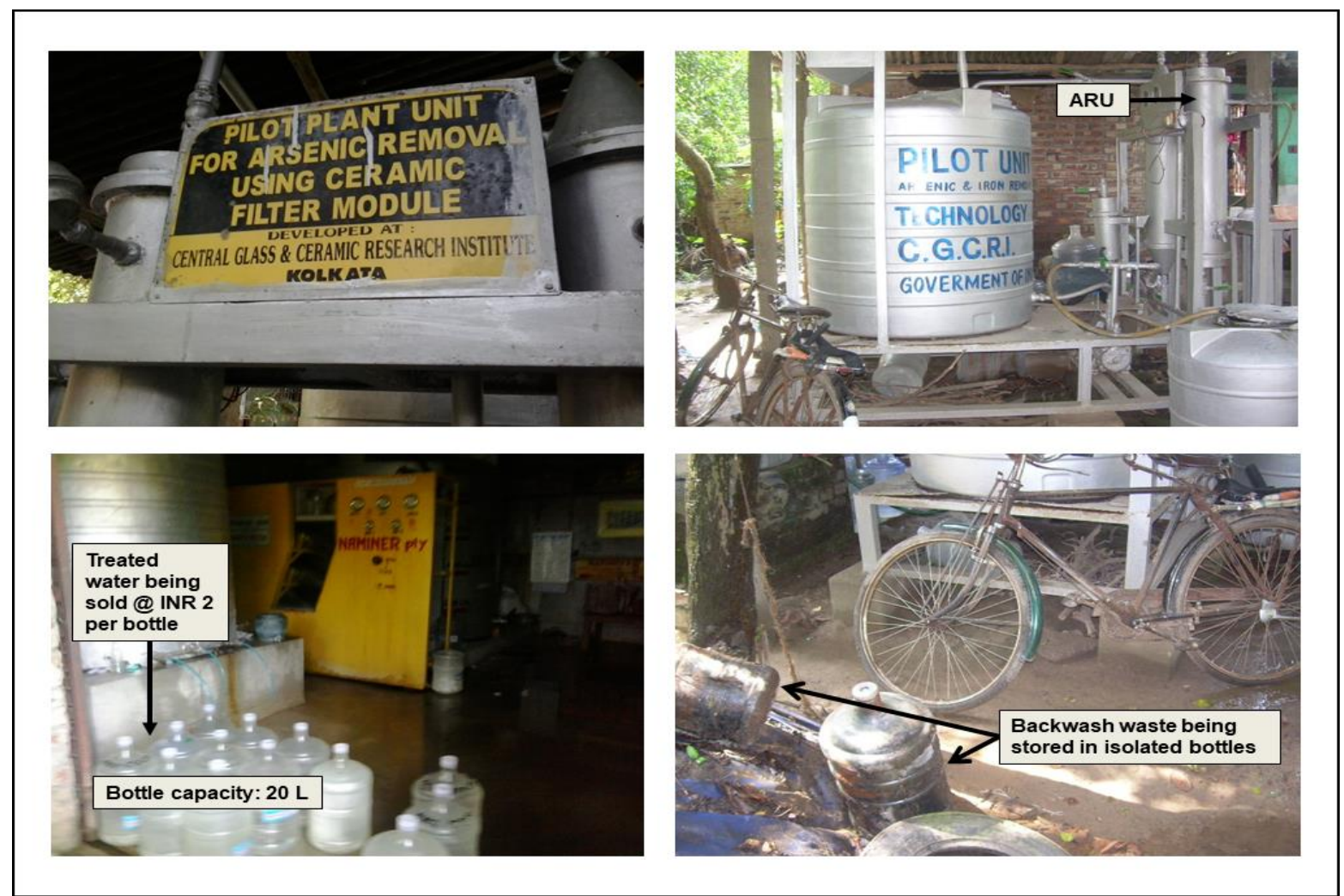

Figure 10 Storage practice for arsenic-sludge by an ARU developed by Central Glass and Ceramic Research Institute, Kolkata, that is located in the Akrampur village of Barasat Municipality, in district North 24 Parganas (adopted from Koley, 2021 [1] with permission of the copyright owner) 


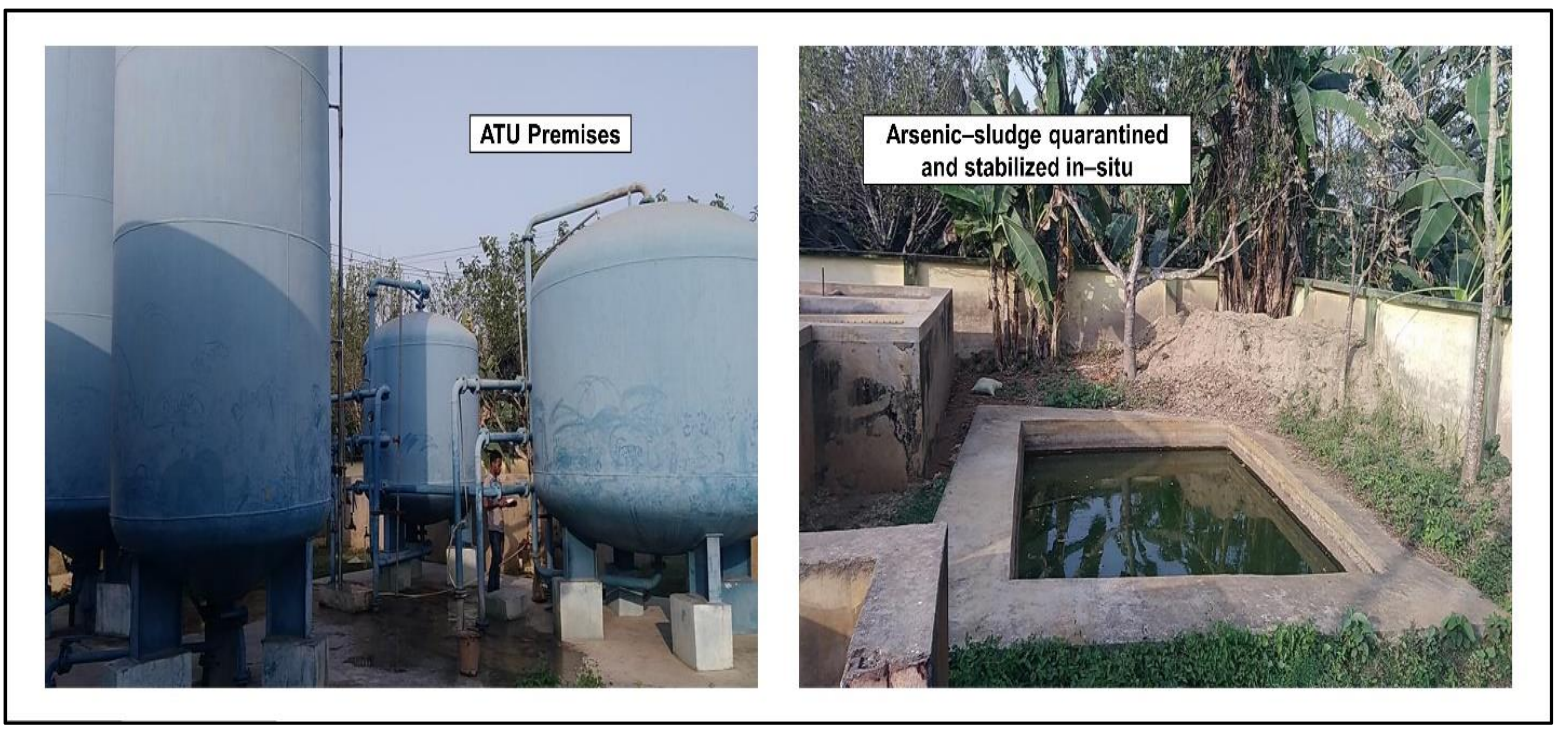

Figure 11(a) Wastewater generated by an ARP located in School Para habitation of the Mrigipota village under Chapra block in district Nadia, commissioned scheme under Bahirgachhi Water Supply Scheme (Zone-2)

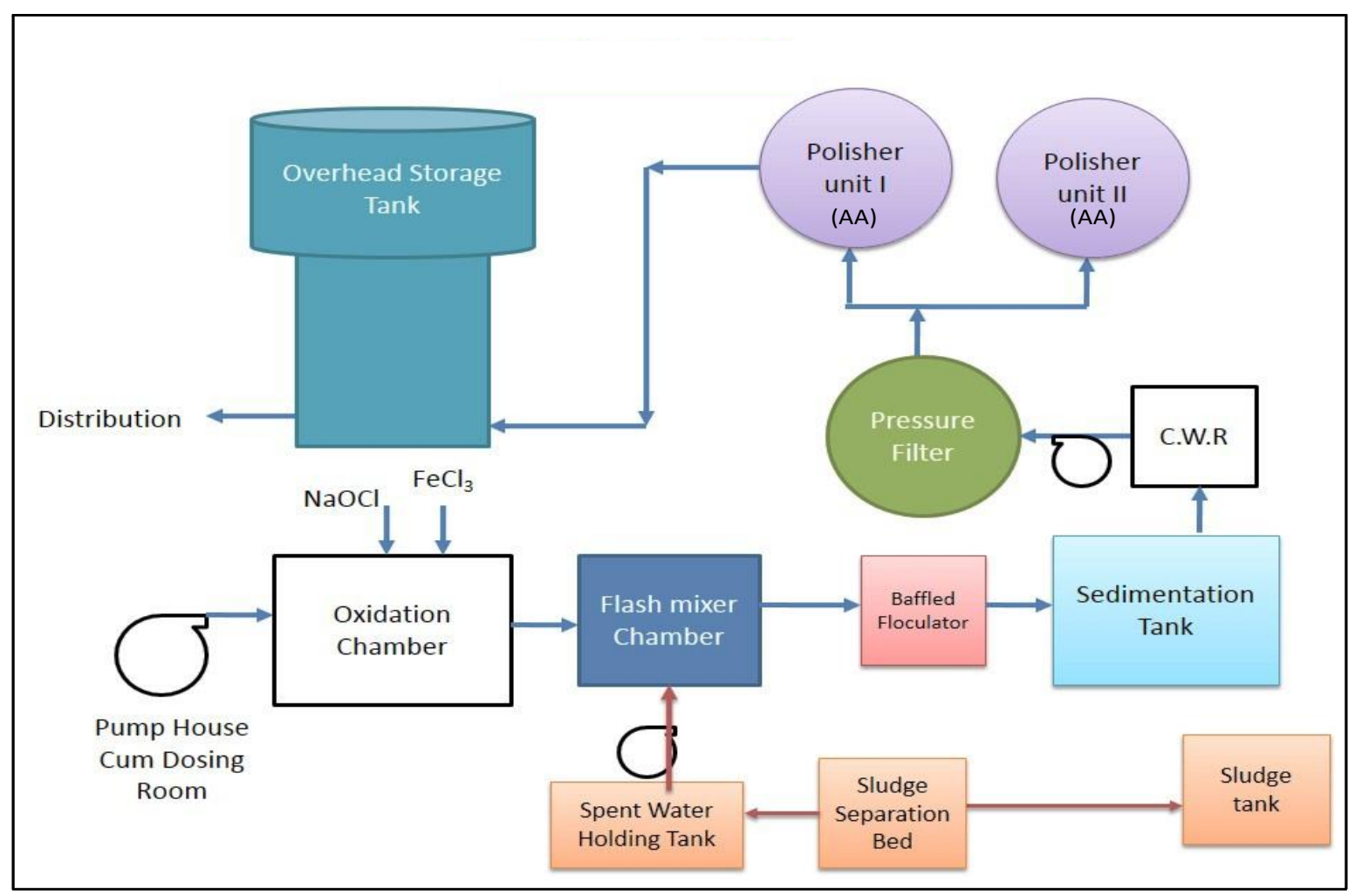

Figure 11(b) Water treatment and wastewater recycling process of an ARP (Note: AA stands for Activated Alumina based water treatment media, and CWR stands for Clear Water Reservoir) 
International Journal of Advanced Technology and Engineering Exploration, Vol 8(80)

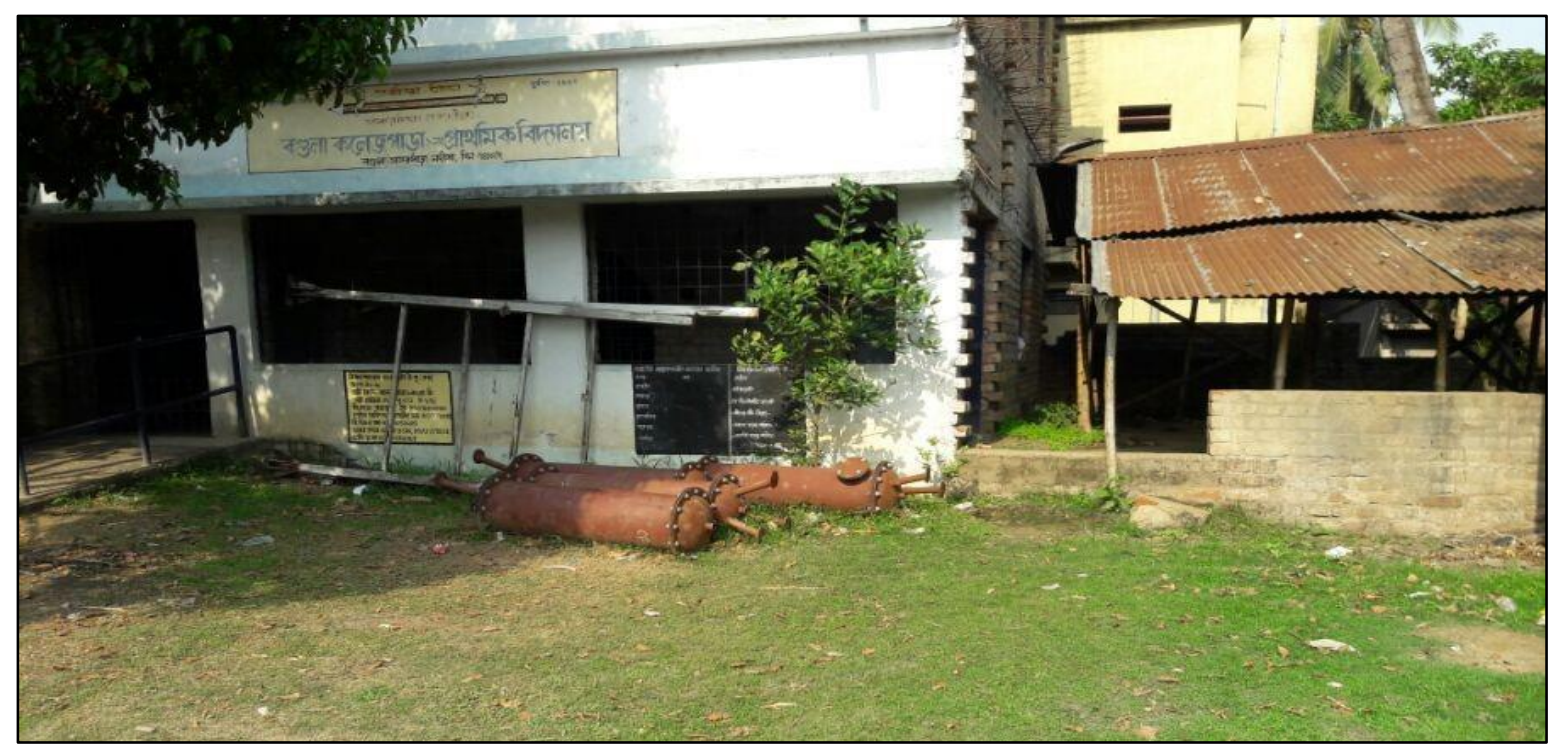

Figure 12(a) Discarded exhausted media of an ARU of Asarpara habitation of Bagula village under Hanskhali block (GP Bagula-I) in district Nadia

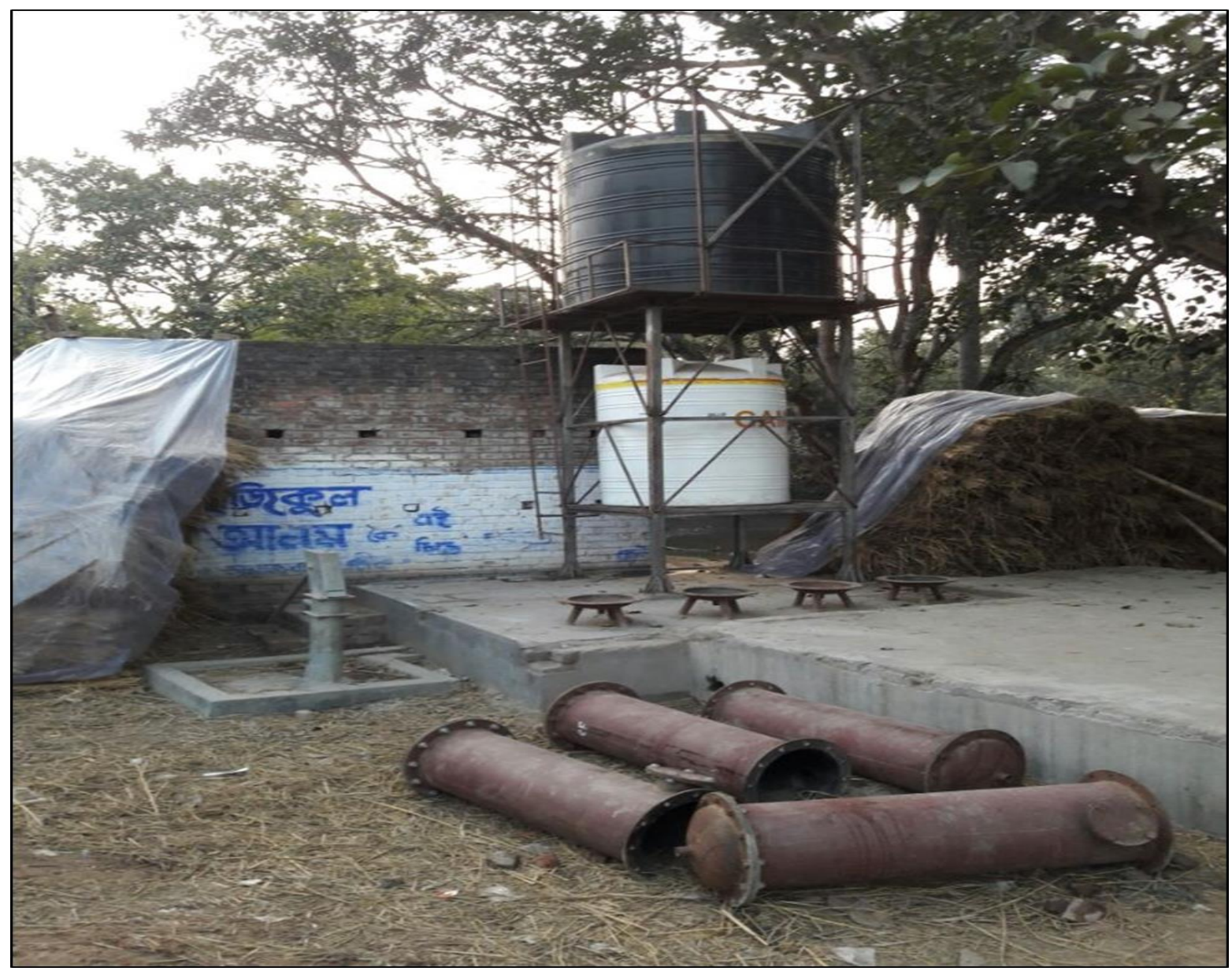

Figure 12(b) Discarded exhausted media of an ARU of Mahatpur habitation of the Mahatpur village under Bhagawangola-I block (GP Sudarpur) in district Murshidabad 
Table 1 Certain prominent ATUs in West Bengal, India (Data assimilation based on Koley, 2014 [31])

\begin{tabular}{|c|c|c|c|c|c|c|c|c|c|}
\hline \multirow[t]{2}{*}{$\begin{array}{l}\text { Manuf acturer } \\
\text { providing Arsenic } \\
\text { treatment technology }\end{array}$} & \multirow{2}{*}{$\begin{array}{l}\text { The location } \\
\text { field visits } \\
\\
\text { Village and } \\
\text { District } \\
\end{array}$} & \multirow{2}{*}{$\begin{array}{l}\text { identified on } \\
\\
\begin{array}{l}\text { Gram } \\
\text { Panchayat }^{\alpha}\end{array} \\
\end{array}$} & \multirow[t]{2}{*}{$\begin{array}{ll}\begin{array}{l}\text { Principle } \\
\text { operation }\end{array} & \text { of } \\
\end{array}$} & \multirow[t]{2}{*}{ Filter Media } & \multirow[t]{2}{*}{$\begin{array}{l}\text { Media } \\
\text { capacity } \\
\text { for water } \\
\text { treatment }\end{array}$} & \multirow[t]{2}{*}{$\begin{array}{l}\text { Annual } \\
\text { expenditure } \\
\text { (in INR) }\end{array}$} & \multicolumn{2}{|c|}{$\begin{array}{l}\text { Efficacy in } \\
\text { removal of } \\
\text { Arsenic } \\
\text { and Iron to } \\
\text { below } 0.05 \\
\mathrm{mg} / \mathrm{L}\end{array}$} & \multirow{2}{*}{$\begin{array}{l}\text { Total } \\
\text { water los } \\
\text { during } \\
\text { treatment } \\
\text { (\% } \\
\text { volume of } \\
\text { feed } \\
\text { water) }\end{array}$} \\
\hline & & & & & & & $\begin{array}{l}\text { As } \\
(\%)\end{array}$ & $\begin{array}{l}\mathrm{Fe} \\
(\%)\end{array}$ & \\
\hline \multirow[t]{2}{*}{$\begin{array}{ll}\text { Public } & \text { Health } \\
\text { Engineering } & \\
\text { Department } & \text { (PHED) } \\
\text { technology, Govt. of } \\
\text { West Bengal (ARP) }\end{array}$} & $\begin{array}{l}\text { Nutanmath } \\
\text { Bholadanga } \\
\text { village, } \\
\text { Santipur } \\
\text { block, } \\
\text { district } \\
\text { Nadia }\end{array}$ & $\begin{array}{l}\text { JL No. } 4 \text { and } \\
\text { GP } \\
\text { Gayeshpur } \\
\text { (code 08) }\end{array}$ & Adsorption & $\begin{array}{l}\text { Hematite }+ \\
\text { Activated } \\
\text { Alumina (AA) + } \\
\text { Manganese } \\
\text { green sand }\end{array}$ & $\begin{array}{l}600 \quad- \\
1,000 \mathrm{~L} / \mathrm{h}\end{array}$ & $\begin{array}{l}85,000 \\
\text { capitals } \quad+ \\
1,680 \quad \text { for } \\
\text { O\&M }\end{array}$ & 95 & 95 & 2 \\
\hline & $\begin{array}{l}\text { Gobardanga } \\
\text { town, } \\
\text { district N24 } \\
\text { Pgs. }\end{array}$ & $\begin{array}{l}\text { Ward No. 11, } \\
\text { Gobardanga } \\
\text { Municipality }\end{array}$ & & & $\begin{array}{l}22,500 \\
\mathrm{~L} / \mathrm{h}\end{array}$ & $\begin{array}{lr}39,00,000 & \\
\text { capitals } & + \\
7.5 \% & \text { for } \\
\text { O\&M } & \end{array}$ & & & \\
\hline $\begin{array}{l}\text { AMAL unit developed } \\
\text { by Bengal Engineering } \\
\text { \& Science University } \\
\text { (BESU), Shibpur } \\
\text { (ARU) }\end{array}$ & $\begin{array}{l}\text { Parpatna } \\
\text { village, } \\
\text { Deganga } \\
\text { block, } \\
\text { district N24 } \\
\text { Pgs. }\end{array}$ & $\begin{array}{l}\text { JL No. } 45 \text { and } \\
\text { GP Chakla } \\
(\text { code } 04)\end{array}$ & Adsorption & $\begin{array}{l}\text { Activated } \\
\text { Alumina (AA) }\end{array}$ & $125 \mathrm{~L} / \mathrm{h}$ & $\begin{array}{l}57,000 \text { capital } \\
+\quad 18,500 \\
\text { O\&M, } \\
\text { including } \\
4,500 \text { for } \\
\text { media } \\
\text { regeneration }\end{array}$ & 95 & 90 & $1-2$ \\
\hline $\begin{array}{l}\text { Pal Trockner Pvt. Ltd., } \\
\text { Kolkata (ARU) }\end{array}$ & $\begin{array}{l}\text { Ichhapur } \\
\text { village, } \\
\text { Gaighata } \\
\text { block, } \\
\text { district N24 } \\
\text { Pgs. } \\
\end{array}$ & $\begin{array}{l}\text { JL No. } 36 \text { and } \\
\text { GP Ichhapur I } \\
(\text { code } 06)\end{array}$ & Adsorption & $\begin{array}{l}\text { Granular Ferric } \\
\text { Hydroxide } \\
(\text { GFH }) \text { called } \\
\text { AdsorpAs }^{\circledR}\end{array}$ & $\begin{array}{l}450-680 \\
\mathrm{~L} / \mathrm{h}\end{array}$ & $\begin{array}{l}77,400 \\
\text { capitals }+ \\
26,000 \text { per } \\
\text { recharging }\end{array}$ & 98 & 91 & 1 \\
\hline $\begin{array}{l}\text { All India Institute of } \\
\text { Hygiene \& Public } \\
\text { Health (AIIH \& PH), } \\
\text { Kolkata (ARU) }\end{array}$ & $\begin{array}{l}\text { Simulpur } \\
\text { village, } \\
\text { Habra-I } \\
\text { block, } \\
\text { district N24 } \\
\text { Pgs. }\end{array}$ & $\begin{array}{l}\text { JL No. } 154 \\
\text { and } \quad \text { GP } \\
\text { Maslandapur } \\
\text { II (code 05) }\end{array}$ & $\begin{array}{l}\mathrm{Co}- \\
\text { precipitation } \\
\text { assisted } \\
\text { microfiltration }\end{array}$ & $\begin{array}{l}\text { Bleaching } \\
\text { powder } \\
\text { Calculated } \\
\begin{array}{l}\text { Ferric Alum } \\
\text { dose }\end{array}\end{array}$ & $1,000 \mathrm{~L} / \mathrm{h}$ & $\begin{array}{l}51,480 \text { capital } \\
+\quad 21,125 \\
\text { O\&M, } \\
\text { including } \\
\text { periodic } \\
\text { chemical } \\
\text { reagents' } \\
\text { charges }\end{array}$ & 95 & 90 & 5 \\
\hline $\begin{array}{l}\text { AnirEngineering (AE) } \\
\text { Kolkata, in } \\
\text { collaboration with ITP } \\
\text { GmbH, Germany } \\
(\mathrm{ARU})\end{array}$ & $\begin{array}{l}\text { Faridpur } \\
\text { village, } \\
\text { Kaliganj } \\
\text { block, } \\
\text { district } \\
\text { Nadia } \\
\end{array}$ & $\begin{array}{l}\text { JL No. } 91 \text { and } \\
\text { GP Faridpur } \\
(\text { code } 03)\end{array}$ & Adsorption & $\begin{array}{l}\text { Granular/slurry } \\
\text { Ferric } \\
\text { Hydroxide } \\
(\text { GFH/SFH) }\end{array}$ & $\begin{array}{l}\text { 600-900 } \\
\mathrm{L} / \mathrm{h}\end{array}$ & $\begin{array}{l}815 \text { capitals }+ \\
192 \quad \text { per } \\
\text { recharge }+27 \\
\text { for O\&M }\end{array}$ & 90 & 90 & $1-2$ \\
\hline $\begin{array}{lr}\text { Central } & \text { Glass \& } \\
\text { Ceramic } & \text { Research } \\
\text { Institute } & \text { (CGCRI), } \\
\text { Kolkata } & \end{array}$ & $\begin{array}{l}\text { Village } \\
\text { Akrampur } \\
\text { Talikhola, } \\
\text { district N24 } \\
\text { Pgs. } \\
\end{array}$ & $\begin{array}{l}\text { Ward No. 4, } \\
\text { Barasat } \\
\text { Municipality }\end{array}$ & \begin{tabular}{l}
\multicolumn{2}{l}{ Adsorption } \\
followed by \\
cross flow \\
microfiltration
\end{tabular} & $\begin{array}{l}\text { Colloidal } \\
\text { adsorbent media } \\
+\quad \text { fabricated } \\
\text { ceramic } \\
\text { cartridge }\end{array}$ & $2,500 \mathrm{~L} / \mathrm{d}$ & $\begin{array}{l}2,96,000 \\
\text { capitals }+4 \% \\
\text { O\&M }\end{array}$ & 96 & 92 & 5 \\
\hline
\end{tabular}

${ }^{\circ}$ A Gram Panchayat (i.e., GP) is basically a cluster of villages for which a particular identification code number is assigned by Zila Parishad(i.e., District Council). JL number refers to the jurisdiction list number allotted by the land reforms department of the state government. For municipalities, a ward number is assigned. Also note, only 1 ARP (i.e., the one in Gobardanga Municipality) currently exists and operatesinthe district North 24 Parganas. Monet ary data are inclusive of taxes, wherever applicable.

\section{Toxicity of the arsenic wastes}

Arsenic in the wastes of ATUs is found to be mainly sorbed onto amorphous iron and aluminum oxyhydroxides in such wastes [94]. Some of the testing methods which have been devised to check arsenic's leaching potential in such wastes include Extraction Procedure Toxicity Test (EPTox), Toxicity Characteristic Leaching Procedure (TCLP) [95], Waste Extraction Test [96], and Australian Bottle Leaching Procedure [97]. As per USEPA, over $5 \mathrm{mg} / \mathrm{L}$ arsenic content in TCLP leachate qualifies the waste as hazardous [98]. However, the credibility of TCLP in estimating the leaching behavior of contaminants in hazardous waste sites has been questioned many a times [99, 100]. In certain case studies, it has been recognized that arsenic-release in a landfill depends on prevalent redoxconditions and their rate of change, the arsenic concentration in the wastes, and chemical composition of landfill leachate which varies from landfill to landfill [101, 102]. Therefore, development of a common or universal method in estimating 
arsenic-release in variable environmental conditions remains a challenge. Nevertheless, TCLP is perceived as being good enough to have an approximate estimation of the toxicity characteristics of wastes, and is widely adopted for arsenic-release estimation [103]. Table 2 shows the recorded values of concentration of arsenic in TCLP extracts of the waste samples. Arsenic contents of the samples were first determined by a semi-quantitative Wavelength Dispersive $\mathrm{X}$-ray Fluorescence (WDXRF) analysis. TCLP extraction tests were conducted on the samples based on the guidelines and procedure laid out by the USEPA's Method Number 1311 [104]. It can be seen, that although the values of arsenic concentrations in the TCLP extracts of some wastes are less than the USEPA standards [105], suggesting that they are nonhazardous, the leaching is high with respect to the Indian regulatory standards for effluent discharge from water treatment units [106].

Table 2 Leached contents of arsenic from wastes, estimated by TCLP

\begin{tabular}{|c|c|c|c|c|c|}
\hline Arsenic Waste & Arsenic Treatment Unit (ATU) & $\begin{array}{l}\text { Arsenic } \\
\text { (mg/L) }\end{array}$ & content & $\begin{array}{l}\text { Arsenic in } \\
(\mathrm{mg} / \mathrm{L})\end{array}$ & extract \\
\hline Spent AA media & Public Health Engineering Department & 860 & & 0.10 & \\
\hline $\begin{array}{ll}\begin{array}{l}\text { Spent } \\
\text { media }\end{array} & \text { GFH } \\
\end{array}$ & Anir Engineering & 650 & & 0.20 & \\
\hline $\begin{array}{l}\text { Backwash } \\
\text { sludge }\end{array}$ & Central Glass \& Ceramic Research Institute & 16,520 & & 15.00 & \\
\hline
\end{tabular}

\section{Waste management methods}

\subsection{Prevalent practices}

Mixing of arsenic-sludge with livestock waste (e.g., cow-dung and poultry wastes), followed by detaining the mixture in an enclosed biogas plant or open soakpit, is often a preferred disposal method in remote habitations of India [107, 108], as most of the arsenic was reported to be removed within a time frame of 3 5 months in this process. Validity of bioremediation of arsenic wastes with such organic wastes under aerobic and anaerobic conditions has been evaluated by various studies $[109,110]$. It has been ascertained that arsenic is removed in this process mainly due to volatilization as a result of biotic transformation of arsenic species by microbial action, thereby unleashing toxic $\mathrm{As}\left(\mathrm{CH}_{3}\right)_{3}$ (trimethylarsine) and $\mathrm{AsH}_{3}$ (arsine) gases, which would have adverse impact to health of villagers living in proximity [111, 112]. Besides, it is a conventional practice in rural areas to obtain a dry cow-dung readily available from the soak pits for cooking purposes. Reportedly, gases liberated by burning of such arsenic containing solids in domestic ovens have indeed led to acute respiratory problems, especially in cases where kitchens are inadequately ventilated [113]. Thus, there are noteworthy health repercussions of using bio-wastes in attempts to reduce the toxicity of arsenic-sludge.

Nonetheless, in an immutable absence of explicit guidelines for waste disposal [114], fixation of a hazardous arsenic waste by stabilization has been assessed to be the most suitable option for long-term sequestration of arsenic in the environment and inhibition of its leaching [115]. Stabilization of ars enic wastes can be done by commercially or naturally available adsorbents in required proportions [116]. But most of the stabilization methods are not enforceable in a sustainable manner in a remote rural setting of India due to lack of requisite resources, awareness and skills. This is evident in Table 3, that briefly shows the literature data on management practices followed by rural communities for disposal of the arsenic-sludge and exhausted media, in the context of some of the ATUs described in Table 1. In yesteryears, the arsenic-sludge was simply discharged in nearby landfills, or in municipal-wastewater drains that were mostly channelled towards local ponds and lakes. But it has been examined that repetitive loading of higharsenic-rich wastes on a particular disposal site could lead to excessive leaching of arsenic, especially under highly alkaline conditions, and presence of arsenic competing bicarbonate $\left(\mathrm{HCO}^{3-}\right)$ and phosphate $\left(\mathrm{H}_{2} \mathrm{PO}_{4}^{-}\right)$anions in the leachate [101]. Also, the leaching process gets instigated or stimulated in a reducing environment [117]. Indiscriminate open disposal of high volumes of such hazardous wastes would therefore certainly lead to serious recontamination of underlying aquifers. Moreover, such leachate-impacted groundwater systems may become on-going sources of contamination of nearby surface water bodies as well [118]. It thus becomes important to strictly check such practices and consider alternative methods for hazard-free stabilization of the wastes. 
Table 3 Information on current waste disposal and reuse practices at some ATU sites (Data assimilation based on Koley, 2014 [31])

\begin{tabular}{|c|c|c|}
\hline ATU & \multicolumn{2}{|c|}{ Practices for arsenic-sludge recovery and disposal } \\
\hline \multirow[t]{9}{*}{ AMAL } & \multirow{3}{*}{ Media restoration process } & Monthly backwash of the system \\
\hline & & Regeneration of spending media in a year \\
\hline & & Replacement of the exhausted media by fresh media \\
\hline & \multirow{3}{*}{ Waste produced } & Wet sludge, as the regenerant solution \\
\hline & & Exhausted adsorbent (AA) media, after few times of regeneration \\
\hline & & Clogged sand filter due to build-up of backwash sludge disposed of it \\
\hline & \multirow[t]{3}{*}{ Waste disposal methods } & $\begin{array}{l}\text { Wet sludge mixed with fly ash, followed by discharge in aerated soak-pit } \\
\text { filters }\end{array}$ \\
\hline & & Exhausted media, crushed and discharged in domestic wastewater drains \\
\hline & & Clogged sand filters are used in cement mortars (up to $5 \%$ by weight) \\
\hline \multirow[t]{6}{*}{ Pal Trockner } & \multirow[t]{2}{*}{ Media restoration process } & Monthly backwash of the system \\
\hline & & Media is non-regenerative, so the media is replaced after exhaustion \\
\hline & \multirow[t]{2}{*}{ Waste produced } & Spent adsorbent (GFH) media \\
\hline & & Wet sludge, as brine wastewater upon media backwash \\
\hline & \multirow[t]{2}{*}{ Waste disposal methods } & Spent media, reused with clay bricks (at 1:6 ratio by weight) \\
\hline & & Wet sludge is discharged in landfills or domestic wastewater drains \\
\hline \multirow[t]{3}{*}{ AIIH \& $\mathrm{PH}^{\beta}$} & Media restoration process & Daily backwash of the system \\
\hline & Waste produced & Slurry containing coagulated arsenic-iron flocs \\
\hline & Waste disposal techniques & $\begin{array}{l}\text { Slurry is reused with clay-bricks or ready-mix concrete (up to } 10 \% \text { by } \\
\text { volume) }\end{array}$ \\
\hline \multirow[t]{7}{*}{ PHED } & \multirow[t]{2}{*}{ Media restoration process } & Weekly backwash of the system \\
\hline & & Replacement of exhausted media in 2 years (no regeneration is done) \\
\hline & \multirow[t]{2}{*}{ Waste produced } & Spent adsorbent media (comprising of manganese sand, hematite and AA) \\
\hline & & Wet sludge, as brine wastewater upon media backwash \\
\hline & \multirow[t]{3}{*}{ Waste disposal methods } & Spent hematite lumps, reused as raw material in steel plants \\
\hline & & $\begin{array}{l}\text { Spent activated alumina, stabilized by Portland Cement (at a 1:10 ratio by } \\
\text { weight) }\end{array}$ \\
\hline & & $\begin{array}{l}\text { Wet sludge is schematically recycled through an underground sludge } \\
\text { separation bed made up of iron-oxide coated bricks }\end{array}$ \\
\hline
\end{tabular}

\subsection{Recent developments in waste management} A field investigation of the ATU sites revealed that a lot of progress has been made in the recent while to prevent inadvertent or unethical dumping of arsenic wastewaters. A proper backwash log-book is maintained at most of the sites, which has resulted in curtailing the incorrect disposal practices of arsenicsludge. This has been possible due to regular inspection by government personnel, and increased awareness and training among the communities handling the ATUs. The ARPs have been potent in curtailing the arsenic-sludge dis posal is sues by way of 'in-situ' stabilization of the waste [31, 119] (as shown earlier in Figure 11(a)). Customarily, systemic arrangements are made in an ARP's premises to recycle the arsenic-rich watergenerated upon periodic backwashes of the water treatment media (as depicted schematically in Figure 11(b)). Separately constructed sludge separation bed (built within the premises itself) adsorbs the arsenic in the recycled water, thereby enabling it to be retreated and further recycled. In order to adsorb and contain the extra arsenic in residual water, the bed can be formed by placing layers of iron-rich river sand on clay-brick chips, while ensuring adequate head space. Consequently, not only is the wastewater from the ARP treated and recycled, but the sludge that is generated as a result, also stays concealed within the unit's premises. However, on a negative note, ARPs distinctly require skilled manpower to set up, along with high technical expertise and frequent supervision for the intricate O\&M, which are not feasible in many remote rural areas having marginal and sparse populations. ARPs are thus difficult to facilitate in remote rural areas lacking vital infrastructural support. Such ATUs lose social acceptability over time, if they are not monitored regularly and operated proficiently [77, 120]. Besides, there always remains a possibility of accidental outflow of arsenic from the sludge separation bed during extreme weather events. On the contrary, the ARUs have been readily and widely accepted by rural households in India as they are easy to manage and operate [77, 107]. But, ARUs generate copious volumes of arsenic-rich wastewater upon 
backwash cleaning of their media. Safe disposal of this toxic wastewater is a burdensome challenge, and therefore it is stored and kept isolated [31]. Unlike the ARPs, not all ARUs have provisions in their premises for 'in-situ' stabilization of the sludge, due to which the sludge is quarantined in drums or in the commonly available PET jars. In some places, where ARUs are installed or run by NGOs and private agencies, these wastes are sold to local manufacturers of value-added construction materials, on a profit or non-profit basis, for its stabilization (Figure 13). But, such an 'ex-situ' arsenic stabilization practice is yet to be adopted by government bodies on a wide-scale so as to ultimately dispose the intense volumes of toxic wastewater generated from various ARUs annually. Nevertheless, following sections comprehensively reveal the information on the current waste management policies.

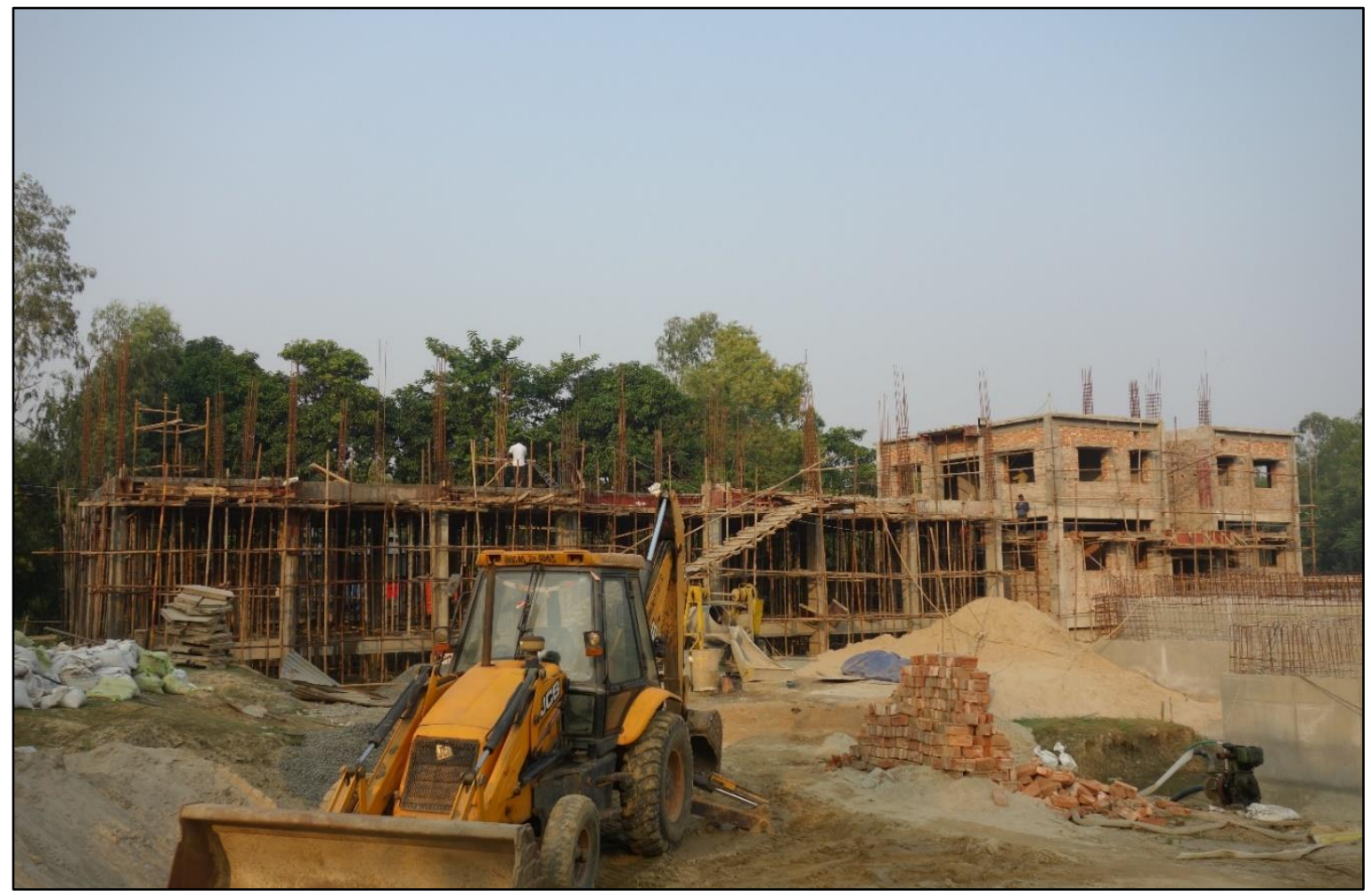

Figure 13 A construction site in Gangarampur Municipality in district Dakshin Dinajpur, utilizing value-added construction materials incorporating waste products such as agricultural residues and municipal wastewaters

\subsubsection{In-situ waste stabilization}

In all ARP sites, and in some ARU sites, the wastewater (i.e., the wet sludge) is kept and monitored in the same premise, by disposal on 'in-situ' constructed open sand filters as sludge separation beds [31,121,122]. However, at most ARU sites where the backwash sludge typically has high turbidity, indicating high toxicity, the sludge is isolated by storage in enclosed drums or the 20 L PET jars (Figure 10). Nonetheless, a sand filter is constructed by digging the ground in a cylindrical or rectangular section to a depth of about $1.5 \mathrm{~m}$ below surface followed by adding layers of fine and coarse-grained sand in the pit. The sides and bottom of the pit are sealed by lining with cement mortar or a mixture of lime and clay, so as to prevent accidental leaching and transport of arsenic and iron due to run-off or infiltration of water during rainfalls. Care is also taken to cover the filters in such situations to prevent arsenic transport by erosion. The upper sand layers are coated with natural iron-oxides to enhance the stabilization process. Marine sediments deposited in the banks of the river Ganges which are rich in goethite and hematite [123], are used as the iron-oxide mineral coatings. By keeping the filters open during the day, adequate aeration is provided for the rapid stabilization of the toxic species of arsenic. As the excess water evaporates, oxidized iron-arsenic complexes remain safely encapsulated in the filter. Disposal of arsenic-sludge of iron-rich sand matrices 
have been found to be suitable for cost-effective insitu inhibition of arsenic leaching under aerobic conditions [124, 125]. At certain sites, brick lining is done at the sides and no sealing is made at the bottom to allow the filtered arsenic-free water to seep into the ground [126]. No adverse impact on groundwater systems in the area has been reported in such cases. The filters are replaced annually with fresh ones. Clogged sand filters are sent to government laboratories where attempts are being made to recover raw arsenic and iron [31]. Decontamination of sand filters can be done on-site by washing with Ethylene Diamine Tetra-acetic acid (EDTA), followed by recovery of arsenic and iron from the resulting chelant solution by silica gel-boned Solid Phase Extraction (SPE) [127, 128]. Regeneration of the SPE system is done by backwashing with $\mathrm{HNO}_{3}$ and the consequent treated chelant solution obtained as a result can be utilized again for recycle as the EDTA. The washed sand filters can be reused or openly discarded on aerated environments. Annual cost of regeneration of a sand filter by this procedure of acidic and caustic wash constitutes $80 \%$ of an ATU's operation and maintenance (i.e., O\&M) cost. Favorably, with regards to volume and arsenic-leaching behavior, the solid wastes and spent regenerant solutions are generally found to be non-hazardous (i.e., arsenic in TCLP leachate is much less than $5 \mathrm{mg} / \mathrm{L}$, as evident in Table 2 ), which dismisses any plausible cause of concern for their disposal.

In a few cases, sludge is mixed with fly ash obtained from ash-pond-dump sites of coal-based thermal power plants located in the rural areas, followed by disposal in aerated soak-pits. This seems alright in theory as fly ash has been found to be very effective in entrapping arsenic due to its high contents of aluminium and ferric oxides that readily adsorb the arsenic [129, 130]. Besides, the recovery of raw arsenic from fly ash can be easily done with acid washing using dilute $\mathrm{H}_{2} \mathrm{SO}_{4}$ [131]. However, all batch experiments recommending such disposal methods have been done with arsenic salts ordinarily available in labs, and none of the experiments used actualsludge (of field conditions) generated from ATUs. Also, no credible information exists on adsorption, desorption and leaching characteristics of other toxic heavy metals like lead, copper, chromium, nickel, cadmium, etc. which accompanies arsenic in the sludge. Moreover, the fly ash itself in the country has been found to contain extremely high concentrations of such pollutants [132]. It also contains trace levels of arsenic and has the potential to contaminate water resources [133]. Hence, the use of hazardous industrial wastes in stabilization or co-disposal of arsenic wastes should be discouraged, as they do not provide practical solutions with regards to sustainable arsenic waste management.

\subsubsection{Ex-situ waste stabilization}

With regards to certain ARUs, stabilization of arsenicbearing sludge by incorporation into construction materials like cement mortars and concrete is quite common (as evident in Table 3), which gives a scope for recycle or reuse of the waste on a commercial scale. Laboratory investigations by batch and column adsorption studies have shown that arsenic is successfully stabilized in ordinary Portland cement due to adsorption with calcium hydroxide [134-136]. It has been identified that mixing up to $40 \%$ of sludge by volume to cement-sand mortar or concrete does not cause significant arsenic leaching [137-139]. For many years, rigorous static and semi-dynamic leaching experiments have been carried out for studying the longstanding leaching behavior of arsenic from the Portland Cement stabilized matrices, and also in combination with other cementitious binders like lime, fly ash, etc. [140-143]. It has been determined that arsenic leaching increases in alkaline conditions due to decalcification or dis solving of ettringite gels as a result of carbonation of calcium-bearing minerals. As cement is typically used in mortars and ready-mix concrete that are mostly exposed to alkaline conditions (e.g., during rainfall), high arsenic leaching from the stabilized product can therefore be anticipated. Moreover, no conclusive information is available on the physical strength characteristics of the stabilized products, which restricts the reuse of arsenic with such materials on a commercial scale.

But, interestingly, stabilization of arsenic-sludge by means of infusion with modular clay-bricks (as in Figure 14) have been supported by numerous studies to be a superior waste management method, which presents another scope for its commercial reuse. In moist clay-moulds prepared for the brick making, initial arsenic adsorption occurs due to electrostatic bonding between positively charged arsenic-bound iron hydroxide solid phases with negatively charged colloidal clay phases [144]. At optimum sludge-mix proportions, the arsenic is effectively encapsulated in the vitrified clay-moulds while burning [86, 145]. Efforts have also been made to determine the best ratio of sludge and firing temperature for maintaining brick durability and strength as a consequence of the addition of sludge [146-148]. It has been concluded that superior or adequate quality sludge-mixed bricks are obtained in the typical firing temperature range of $900-1300^{\circ} \mathrm{C}$ itself. In 1 st-class quality Indian modular 
bricks, the wet sludge is permanently encapsulated, by mixing it homogeneously at $1-10 \%$ by volume. In neutral and alkaline exposure environments, the arsenic-laden bricks can be safely used as ornamental bricks and as a building material in masonry, with the sludge addition of up to $6 \%$ and $4 \%$ by weight, respectively. In every case, arsenic encapsulation is > $98 \%$, with the stabilized brick being non-hazardous in terms of arsenic leaching phenomenon (i.e., arsenic in TCLP leachate $<0.02 \mathrm{mg} / \mathrm{L}$ ). Unfortunately, this is not always true in case of acidic exposure environments (e.g., urban heat is lands, industrial setups, places with high intensity of acid rains, etc.) in which arsenic leaching increases due to dissolution of excess iron hydroxides which fail to find available charges for bonding with clay [144, 145].

Nevertheless, such bricks can be safely used in load or non-load bearing interior walls of residential structures, though such a technique should not be used for stabilizing wastes like a spending media waste containing high amounts of alumina and silica. Excess silica (> 70\% w/w) makes a brick brittle and weak on burning, and excess alumina (> 40\% w/w) produces cracks in brick on drying and makes the bricks refractory $[149,150]$. Also, commercialization of mass scale stabilization of sludge with bricks would result in higher economic benefits to the government and the society, which would help to further invest in arsenic mitigation schemes in the long run. Such benefits have been projected to be of the order of millions of USD, that is worth investing in rural development projects of India [31]. With the booming brick production market in India's alluvial Gangetic plain, it shall be worthwhile to execute a waste management project of arsenic wastes' valorization with bricks, based on the location, character and quantity of the waste to be stabilized. Ex-situ stabilization, through which arsenic-sludge gets permanently restrained in the environment, will help in avoiding long-term storage of the waste and subsequent disposal or processing elsewhere that presents a perpetual risk of accidental leaching of arsenic. In this way, no extra effort, so as to dispose the sludge on-site or off-site of an ARU, is required for the waste management, which saves valuable time and money. Therefore, an ex-situ waste management project shall help the government in achieving robust and sustainable arsenic mitigation (i.e., groundwater remediation and waste management, together) in India.

5.2.3. Integrating water treatment and waste stabilization as a dynamic system

Figure 15 schematically summarizes both the 'in-situ' and 'ex-situ' plan of action, of arsenic mitigation, in two separate scenarios using a dynamic modeling technique. The in-situ management approach mandates arsenic-bearing wastewater to be recycled through iron-rich sand filters located on-site, before adsorption and the sequestration of residual arsenic. The ex-situ management approach is envisaged to make use of clay-bricks at a brick manufacturing factory to stabilize the toxic sludge off-site and in a hazard-free manner. As evident in the diagram, the dynamic model can also perform a cost-benefit analysis in order to calculate the benefit-to-cost ratio for the primary stakeholders (i.e., government and society) in the two scenarios, so as to determine the best mitigation strategy (i.e., water treatment in combination with associated sludge-stabilization aspect) that is deemed to be most sustainable for implementation in the study area. The calculations go clockwise from sectors 1 to 4 in the Figure 15, via feedback loops. Solid and dotted lines with arrow heads manifest positive and negative feedbacks, respectively, between connected entities. Highlighted parameters portray static or predefined values which initiate the feedback response, while others denote the dynamic ones. The model thus created is also designed to estimate the consequent welfare gains (in the form of health benefits) to the society as well. Though slightly complex in nature, the formulation of this analytical model is quite robust, and besides as similating numerous parameters of fiscal data, it also integrates several other factors of demographic changes and the establishment of various watersupply schemes 


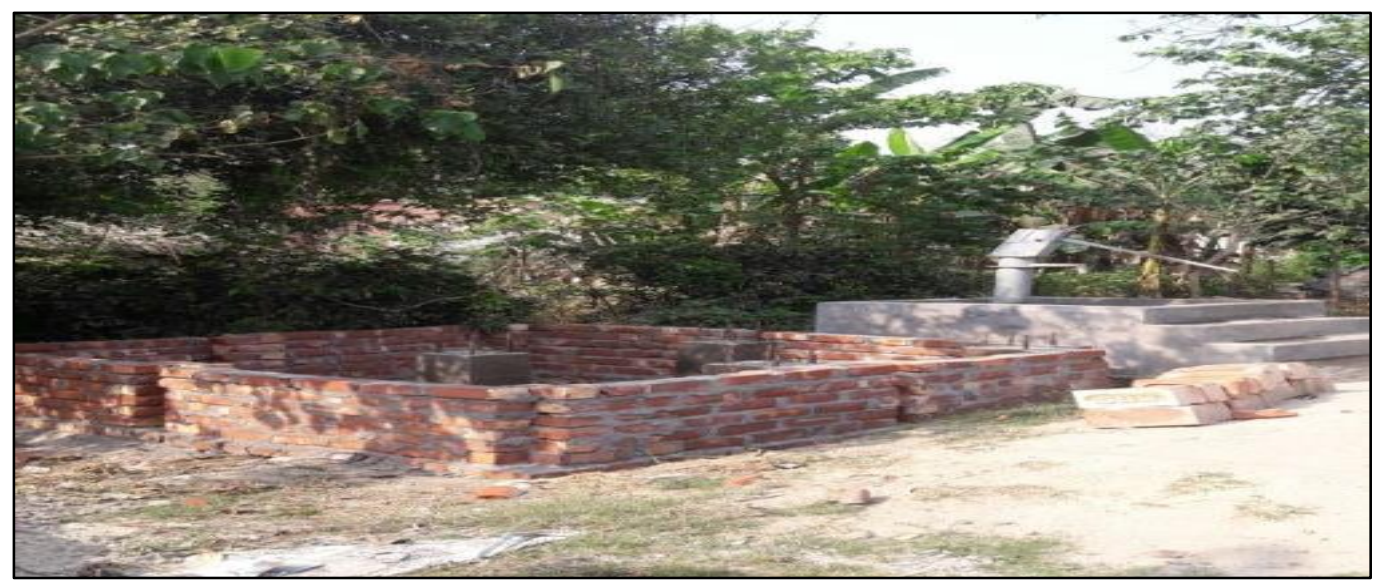

Figure 14 Clay-bricks being used for construction of an ARU in rural West Bengal (location Gosaichar Purbapara habitation of the Gosaichar village under Ranaghat-I block in district Nadia, GP Nawpara Masund

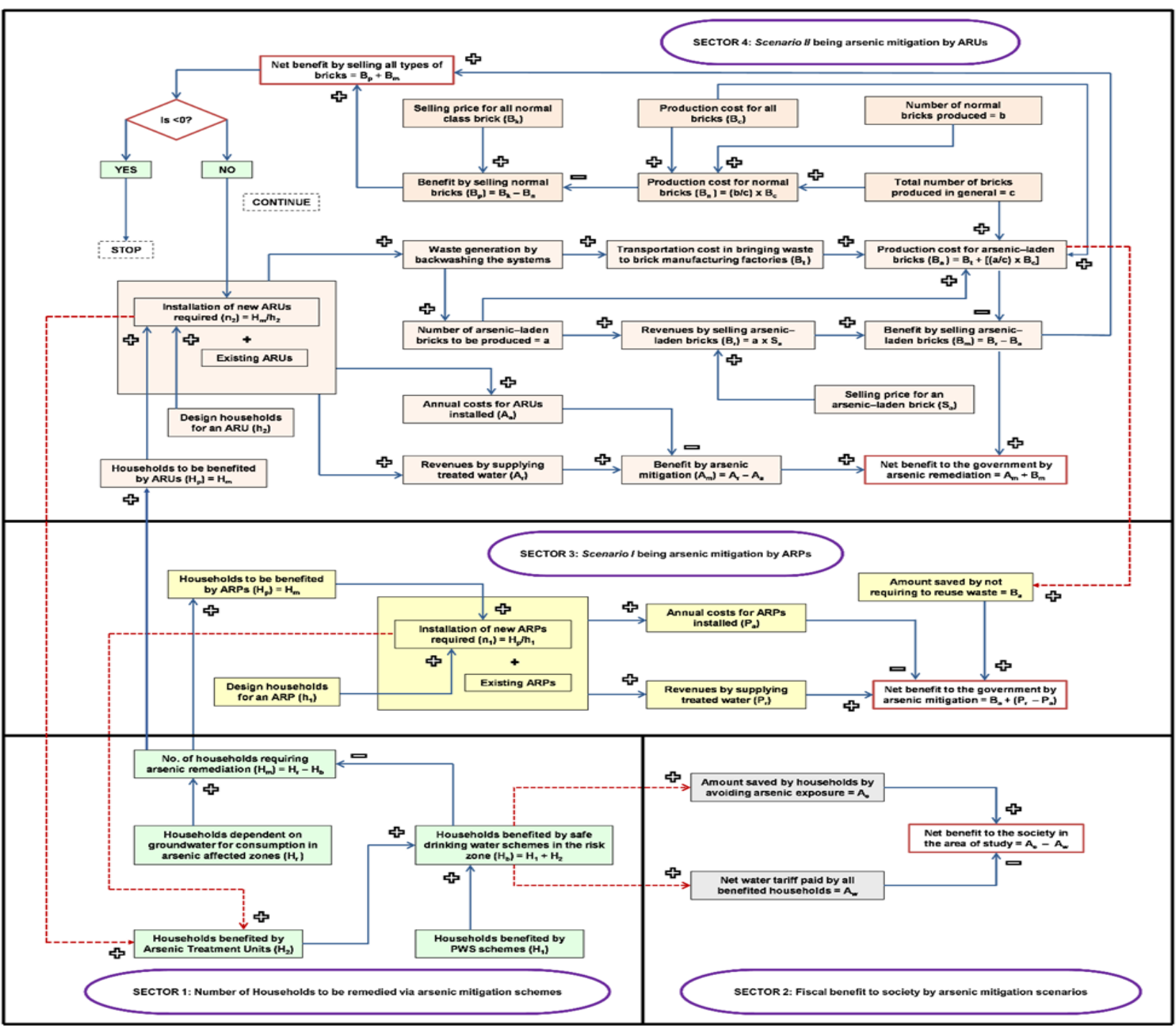

Figure 15 Schematic outline describing the arsenic mitigation strategies as an integrated dynamic system (Note: + sign refers to positive feedback, while - sign denotes negative feedback between the connected components ) 


\section{Conclusion}

Geogenic arsenic contamination of shallow aquifers is a critical issue challenging the socio-environmental progress of the developing world. The situation is worse in a populous nation like India, where the majority of the rural population relies heavily on groundwater for drinking water. For over three decades, millions of households in India's state called West Bengal have been at the tragic end of this public health crisis. Remedial measures involving pipedwater-supply of treated surface water and harvested rainwater are ultimate ways for attaining sustainable arsenic mitigation in such a region. However, these schemes can cater to only a limited population due to logistic and financial constraints. In such a case, the establishment of ATUs, that treat extracted groundwater for providing safe drinking water, would remain as the principal remedy for arsenic remediation in the remote rural habitations of the country. A field investigation of the ATUs revealed that management of toxic and voluminous wastewater generated from these units upon backwash cleaning is necessary to achieve effective arsenic mitigation. Inadvertent and careless disposal of the waste in landfills or municipal drains can lead to recontamination of underlying aquifers, thereby hindering the sustainability of the ATUs. In other words, all the diligent efforts of the ATUs in eliminating arsenic from groundwater become futile in lowering the overall arsenic toxicity of the environment. Therefore, stabilization of the wastewater is vital to encapsulate the arsenic. Practical utilization of industrial wastes or metallurgical byproducts for stabilization or co-disposal of arsenicsludge is also a challenge due to the highly hazardous nature of these substances towards the environment. Yet, in the absence of a robust infrastructure for waste disposal in rural societies, the waste management can be done either by in-situ quarantine and monitoring of the sludge, or by ex-situ recycling or reuse of the waste by stabilization with common building materials such as clay-bricks. A meticulous overview of literature in this regard shows that incorporation of the arsenic-sludge into clay-bricks are a promising solution for the sustainable management of wastewaters in the arsenic mitigation projects.

This review paper proposes a novel solution to the disastrous arsenic problem in West Bengal, India, which addresses both groundwater remediation and waste management issues simultaneously in an environmentally safe and economically sound manner. With this article, a new viewpoint has been offered on the ground realities of arsenic mitigation policies in environmental management projects. Certain ATUs called ARPs have provisions within their premises to stabilize the toxic wastewater in-situ. However, ARPs necessitate enormous area and skilled manpower for investiture and operation, which may not be expedient for a long haul, particularly in a rural setting with sparse populace. On the contrary, several small-scale ATUs called ARUs have been greatly accepted by rural households due to convenience in their use and sustenance. But the ARUs produce high volumes of the hazardous arsenic-sludge, that is normally kept stored on-site, which ultimately require potent stabilization for safe disposal. As establishment of ARPs is not quite reasonable in rustic habitations due to socio-economic barriers, arsenic remediation plan incorporating installation of ARUs and subsequent off-site stabilization of arsenic wastes with bricks must be accomplished for permanent encapsulation of arsenic in the local environment. Ex-situ stabilization, where most of the waste will be utilized to make bricks, while also getting secluded from the environment, will not only assist in preventing longterm storage of the toxic waste, but also prohibit its subsequent disposal elsewhere that has an accompanied risk of accidental leaching of arsenic into the environment. In a post COVID-19 economy, commercial benefits accrued by governmental implementation of such projects shall contribute in poverty alleviation and modernization of the rustic communities as well [151-154]. Policy measures that incorporate such methods should be encouraged and enforced.

\section{Acknowledgment}

None.

\section{Conflicts of interest}

The author declares no conflict of interest. This paper is an original, independent, and a standalone work that adheres to all best practices for publishing. The author's M.Tech thesis has been the inspiration behind writing this review article. No financial or institutional support is involved in any form in preparing this paper.

\section{References}

[1] Koley S. Future perspectives and mitigation strategies towards groundwater arsenic contamination in West Bengal, India. Environmental Quality Management. 2021.

[2] Kapaj S, Peterson H, Liber K, Bhattachary a P. Human health effects from chronic arsenic poisoning-a review. Journal of Environmental Science and Health, Part A. 2006; 41(10):2399-428.

[3] Gentry PR, Clewell III HJ, Greene TB, Franzen AC, Yager JW. The impact of recent advances in research on arsenic cancer risk assessment. Regulatory Toxicology and Pharmacology. 2014; 69(1):91-104. 
[4] Mandal BK, Suzuki KT. Arsenic round the world: a review. Talanta. 2002; 58(1):201-35.

[5] McCarty KM, Hanh HT, Kim KW. Arsenic geochemistry and human health in South East Asia. Reviews on Environmental Health 2011; 26(1):71-8.

[6] Oremland RS, Stolz JF. Arsenic, microbes and contaminated aquifers. Trends in Microbiology. 2005 ;13(2):45-9.

[7] Guo H, Yang S, Tang X, Li Y, Shen Z. Groundwater geochemistry and its implications for arsenic mobilization in shallow aquifers of the Hetao Basin, Inner Mongolia. Science of the Total Environment. 2008; 393(1):131-44.

[8] Biswas A, Majumder S, Neidhardt H, Halder D, Bhowmick S, Mukherjee-goswami A et al. Groundwater chemistry and redox processes: depth dependent arsenic release mechanism. Applied Geochemistry. 2011; 26(4):516-25.

[9] Smedley PL, Kinniburgh DG. A review of the source, behaviour and distribution of arsenic in natural waters. Applied Geochemistry. 2002; 17(5):517-68.

[10] Ford RG, Wilkin RT, Hernandez G. Arsenic cycling within the water column of a small lake receiving contaminated ground-water discharge. Chemical Geology. 2006; 228(1-3):137-55.

[11] Sharma VK, Sohn M. Aquatic arsenic: toxicity, speciation, transformations, and remediation. Environment International. 2009; 35(4):743-59.

[12] http://monographs.iarc.fr/ENG/Monographs/vol84/. Accessed 10 May 2021.

[13] Hanh HT, Kim JY, Bang S, Kim KW. Sources and fate of as in the environment. Geosystem Engineering. 2010; 13(1):35-42.

[14] Yoshida T, Yamauchi H, Sun GF. Chronic health effects in people exposed to arsenic via the drinking water: dose-response relationships in review. Toxicology and Applied Pharmacology. 2004; 198(3):243-52.

[15] Vahter ME, Li L, Nermell B, Rahman A, Arifeen SE, Rahman M, et al. Arsenic exposure in pregnancy: a population-based study in Matlab, Bangladesh. Journal of Health, Population and Nutrition. 2006; 24(2):23645.

[16] Tsuji JS, Alexander DD, Perez V, Mink PJ. Arsenic exposure and bladder cancer: quantitative assessment of studies in human populations to detect risks at low doses. Toxicology. 2014; 317:17-30.

[17] World Health Organization. Guidelines for drinkingwater quality. World Health Organization; 1993.

[18] Datta DK, Subramanian V. Distribution and fractionation of heavy metals in the surface sediments of the Ganges-Brahmaputra-M eghna river sy stem in the Bengal basin. Environmental Geology. 1998; 36:93101.

[19] Mcarthur JM, Banerjee DM, Hudson-edwards KA, Mishra R, Purohit R, Ravenscroft P, et al. Natural organic matter in sedimentary basins and its relation to arsenic in anoxic ground water: the example of West Bengal and its worldwide implications. Applied Geochemistry. 2004; 19(8):1255-93.
[20] Guillot S, Charlet L. Bengal arsenic, an archive of Himalaya orogeny and paleohydrology. Journal of Environmental Science and Health, Part A. 2007; 42(12):1785-94.

[21] Dowling CB, Poreda RJ, Basu AR, Peters SL, Aggarwal PK. Geochemical study of arsenic release mechanisms in the Bengal basin groundwater. Water Resources Research. 2002; 38(9):1-18.

[22] Shamsudduha M, Uddin A. Quaternary shoreline shifting and hy drogeologic influence on the distribution of groundwater arsenic in aquifers of the Bengal basin. Journal of Asian Earth Sciences. 2007; 31(2):177-94.

[23] Van GA. International drilling to recover aquifer sands (IDRAs) and arsenic contaminated groundwater in Asia. Scientific Drilling. 2011; 12:49-52.

[24] Chakraborti D, Rahman MM, Paul K, Chowdhury UK, Sengupta MK, Lodh D, et al. Arsenic calamity in the Indian subcontinent: what lessons have been learned? Talanta. 2002; 58(1):3-22.

[25] Fendorf S, Michael HA, Van GA. Spatial and temporal variations of groundwater arsenic in South and Southeast Asia. Science. 2010; 328(5982):1123-7.

[26] https://jalshaktiddws.gov.in/sites/default/files/JJM_Operational_Guid elines.pdf. Accessed 10 May 2021.

[27] Charlet L, Polya DA. Arsenic in shallow, reducing groundwaters in southern Asia: an environmental health disaster. Elements. 2006; 2(2):91-6.

[28] Ghosh NC, Singh RD. Groundwater arsenic contamination in India: vulnerability and scope for remedy.

[29] https://www.wbphed.gov.in/en/home. Accessed 10 May 2021.

[30] Jing C, Liu S, Patel M, Meng X. Arsenic leachability in water treatment adsorbents. Environmental Science \& Technology. 2005; 39(14):5481-7.

[31] http://etd.iitk.ac.in:8080/jspui/handle/123456789/1418 9. Accessed 10 May 2021.

[32] Mandal BK, Chowdhury TR, Samanta G, Basu GK, Chowdhury PP, Chanda CR, et al. Arsenic in groundwater in seven districts of West Bengal, Indiathe biggest arsenic calamity in the world. Current Science. 1996; 70(11):976-86.

[33] Achary y SK, Lahiri S, Raymahashay BC, Bhowmik A. Arsenic toxicity of groundwater in parts of the Bengal basin in India and Bangladesh: the role of quaternary stratigraphy and Holocene sea-level fluctuation. Environmental Geology. 2000; 39:112737.

[34] Mukherjee A, Fryar AE, Thomas WA. Geologic, geomorphic and hydrologic framework and evolution of the Bengal basin, India and Bangladesh. Journal of Asian Earth Sciences. 2009; 34(3):227-44.

[35] Neidhardt H, Berner ZA, Freikowski D, Biswas A, Majumder S, Winter $\mathrm{J}$, et al. Organic carbon induced mobilization of iron and manganese in a West Bengal aquifer and the muted response of groundwater arsenic concentrations. Chemical Geology. 2014; 367:51-62.

[36] Nickson RT, McArthur JM, Ravenscroft P, Burgess WG, Ahmed KM. Mechanism of arsenic release to 
groundwater, Bangladesh and West Bengal. Applied Geochemistry. 2000; 15(4):403-13.

[37] Stüben D, Berner Z, Chandrasekharam D, Karmakar J. Arsenic enrichment in groundwater of West Bengal, India: geochemical evidence for mobilization of as under reducing conditions. Applied Geochemistry. 2003; 18(9):1417-34.

[38] Guha S, Ray mahashay BC, Banerjee A, Acharyy a SK, Gupta A. Collection of depth-specific groundwater samples from an arsenic contaminated aquifer in West Bengal, India. Environmental Engineering Science. 2005; 22(6):870-81.

[39] Berg M, Trang PT, Stengel C, Buschmann J, Viet PH, Van DN et al. Hydrological and sedimentary controls leading to arsenic contamination of groundwater in the Hanoi area, Vietnam: the impact of iron-arsenic ratios, peat, river bank deposits, and excessive groundwater abstraction. Chemical Geology. 2008; 249(1-2):91112.

[40] Mallick S, Rajagopal NR. Groundwater development in the arsenic-affected alluvial belt of West Bengal-some questions. Current Science. 1996; 70(11):956-8.

[41] Das D, Samanta G, Mandal BK, Chowdhury TR, Chanda CR, Chowdhury PP, et al. Arsenic in groundwater in six districts of West Bengal, India. Environmental Geochemistry and Health. 1996; 18(1):5-15.

[42] Mandal BK, Chowdhury TR, Samanta G, Mukherjee DP, Chanda CR, Saha KC, et al. Impact of safe water for drinking and cooking on five arsenic-affected families for 2 years in West Bengal, India. Science of the Total Environment. 1998; 218(2-3):185-201.

[43] Mukherjee A, Fryar AE, Scanlon BR, Bhattachary a P, Bhattacharya A. Elevated arsenic in deeper groundwater of the western Bengal basin, India: extent and controls from regional to local scale. Applied Geochemistry. 2011; 26(4):600-13.

[44] Bagla P, Kaiser J. India's spreading health crisis draws global arsenic experts. Science. 1996; 274(5285):1745.

[45] Chowdhury TR, Basu GK, Mandal BK, Biswas BK, Samanta G, Chowdhury UK, et al. Arsenic poisoning in the Ganges delta. Nature. 1999; 401:545-6.

[46] Pandey PK, Yadav S, Nair S, Bhui A. Arsenic contamination of the environment: a new perspective from central-east India. Environment International. 2002; 28(4):235-45.

[47] Bose P, Sharma A. Role of iron in controlling speciation and mobilization of arsenic in subsurface environment. Water Research. 2002; 36(19):4916-26.

[48] Bhattachary a P, Welch AH, Ahmed KM, Jacks G, Naidu R. Arsenic in groundwater of sedimentary aquifers. Applied Geochemistry. 2004; 19(2):163-7.

[49] Mukherjee A, Scanlon BR, Fry ar AE, Saha D, Ghosh A, Chowdhuri S et al. Solute chemistry and arsenic fate in aquifers between the Himalay an foothills and Indian craton (including central Gangetic plain): influence of geology and geomorphology. Geochimica et Cosmochimica Acta. 2012; 90:283-302.
[50] Kim SH, Kim K, Ko KS, Kim Y, Lee KS. Cocontamination of arsenic and fluoride in the groundwater of unconsolidated aquifers under reducing environments. Chemosphere. 2012; 87(8):851-6.

[51] Chakroborty C, Chattopadhyay GS. Quaternary geology of south Ganga plain in Bihar. Indian Minerals. 2001; 55(3\&4):133-42.

[52] Chakraborti D, Singh EJ, Das B, Shah BA, Hossain MA, Nay ak B et al. Groundwater arsenic contamination in Manipur, one of the seven North-Eastern hill states of India: a future danger. Environmental Geology. 2008; 56:381-90.

[53] Saha D, Sahu S. A decade of investigations on groundwater arsenic contamination in middle Ganga plain, India. Environmental Geochemistry and Health. 2016; 38:315-37.

[54] Bindal S, Singh CK. Predicting groundwater arsenic contamination: regions at risk in highest populated state of India. Water Research. 2019; 159:65-76.

[55] Patel AK, Das N, Goswami R, Kumar M. Arsenic mobility and potential co-leaching of fluoride from the sediments of three tributaries of the upper Brahmaputra floodplain, Lakhimpur, Assam, India. Journal of Geochemical Exploration. 2019; 203:45-58.

[56] Chowdhury UK, Biswas BK, Chowdhury TR, Samanta G, Mandal BK, Basu GC, et al. Groundwater arsenic contamination in Bangladesh and West Bengal, India. Environmental Health Perspectives. 2000; 108(5):3937.

[57] Uppal JS, Zheng Q, Le XC. Arsenic in drinking water-recent examples and updates from Southeast Asia. Current Opinion in Environmental Science \& Health. 2019; 7:126-35.

[58] Biswas A, Bhattacharya P, Mukherjee A, Nath B, Alexanderson $\mathrm{H}$, Kundu AK, et al. Shallow hydrostratigraphy in an arsenic affected region of Bengal basin: implication for targeting safe aquifers for drinking water supply. Science of the Total Environment. 2014; 485:12-22.

[59] Singh IB. Late quaternary history of the Ganga plain. Journal of Geological Society of India. 2004; 64(4):431-54.

[60] http://cgwb.gov.in/AQM/Pilot/Patna\%20District, \%20 Bihar-Final.pdf. Accessed 10 May 2021.

[61] Joshi H, Ghosh AK, Singhal DC, Kumar S. Arsenic contamination in parts of Yamuna sub-basin, West Bengal. Indian Journal of Environmental Health. 2003; 45(4):265-74.

[62] Michael HA, Voss CI. Evaluation of the sustainability of deep groundwater as an arsenic-safe resource in the Bengal basin. Proceedings of the National Academy of Sciences. 2008; 105(25):8531-6.

[63] Mukherjee A, Fryar AE. Deeper groundwater chemistry and geochemical modeling of the arsenic affected Western Bengal basin, West Bengal, India. Applied Geochemistry. 2008; 23(4):863-94.

[64] Saunders JA, Lee MK, Uddin A, Mohammad S, Wilkin RT, Fayek M, et al. Natural arsenic contamination of Holocene alluvial aquifers by linked tectonic, 
weathering, and microbial processes. Geochemistry, Geophy sics, Geosy stems. 2005; 6(4):1-7.

[65] Mukherjee A, Verma S, Gupta S, Henke KR, Bhattachary a P. Influence of tectonics, sedimentation and aqueous flow cycles on the origin of global groundwater arsenic: paradigms from three continents. Journal of Hy drology . 2014; 518:284-99.

[66] https://www.adb.org/sites/default/files/linkeddocuments/49107-006-sd-01.pdf. Accessed 10 May 2021.

[67] Ahmad A, Heijnen L, De WL, Battaglia-brunet F, Oorthuizen W, Pieterse B, et al. Mobility and redox transformation of arsenic during treatment of artificially recharged groundwater for drinking water production. Water Research. 2020; 178:1-13.

[68] Ahmed MF. An overview of arsenic removal technologies in Bangladesh and India. In proceedings of BUET-UNU international workshop on technologies for arsenic removal from drinking water, Dhaka 2001(pp. 251-69).

[69] Fakhreddine S, Prommer H, Gorelick SM, Dadakis J, Fendorf S. Controlling arsenic mobilization during managed aquifer recharge: the role of sediment heterogeneity. Environmental Science \& Technology. 2020; 54(14):8728-38.

[70] Newman CP, Gray T. Statistical and geochemical fingerprinting analysis of arsenic mobilization and natural background associated with artificial groundwater recharge. Environmental Earth Sciences. 2019; 78:1-6.

[71] Bhattachary a P, Jacks G, Ahmed KM, Routh J, Khan AA. Arsenic in groundwater of the Bengal delta plain aquifers in Bangladesh. Bulletin of Environmental Contamination and Toxicology. 2002; 69:538-45.

[72] Sarkar S, Greenleaf JE, Gupta A, Ghosh D, Blaney LM, Bandy opadhy ay $\mathrm{P}$ et al. Evolution of community-based arsenic removal systems in remote villages in West Bengal, India: assessment of decade-long operation. Water Research. 2010; 44(19):5813-22.

[73] https://niti.gov.in/planningcommission.gov.in/docs/ab outus/committee/wrkgrp 11/tf11_arsenics.pdf. Accessed 10 May 2021.

[74] Watanabe C, Kawata A, Sudo N, Sekiy ama M, Inaoka $\mathrm{T}$, Bae M, et al. Water intake in an Asian population living in arsenic-contaminated area. Toxicology and Applied Pharmacology. 2004; 198(3):272-82.

[75] Hossain MA, Rahman MM, Murrill M, Das B, Roy B, Dey $S$ et al. Water consumption patterns and factors contributing to water consumption in arsenic affected population of rural West Bengal, India. Science of the Total Environment. 2013; 463:1217-24.

[76] Jain CK, Singh RD. Technological options for the removal of arsenic with special reference to South East Asia. Journal of Environmental Management. 2012; 107:1-18.

[77] Etmannski TR, Darton RC. A methodology for the sustainability assessment of arsenic mitigation technology for drinking water. Science of the Total Environment. 2014; 488:505-11.
[78] https://law.resource.org/pub/in/bis/S06/is.10500.2012. pdf. Accessed 10 May 2021.

[79] Jones SA, Joy N. The inequity of the revised arsenic rule for very small community drinking water sy stems. Environmental Science \& Policy. 2006; 9(6):555-62.

[80] http://water.epa.gov/drink/info/arsenic/upload/2005_1 1_10_arsenic_treatments_and_costs.pdf. Accessed 10 May 2021.

[81] Garelick H, Dybowska A, Valsami-jones E, Priest N. Remediation technologies for arsenic contaminated drinking waters (9 pp). Journal of Soils and Sediments. 2005; 5:182-90.

[82] Mondal P, Majumder CB, Mohanty B. Laboratory based approaches for arsenic remediation from contaminated water: recent developments. Journal of Hazardous Materials. 2006; 137(1):464-79.

[83] Giles DE, Mohapatra M, Issa TB, Anand S, Singh P. Iron and aluminium based adsorption strategies for removing arsenic from water. Journal of Environmental Management. 2011; 92(12):3011-22.

[84] http://archive.unu.edu/env/Arsenic/Han.pdf. Accessed 10 May 2021.

[85] Shafiquzzaman M, Azam MS, Nakajima J, Bari QH. Arsenic leaching characteristics of the sludges from iron based removal process. Desalination. 2010; 261(12):41-5.

[86] Bhusan D, S. Treatability study of disposal of arsenic sludge produced from an arsenic removal plant. Unpublished ME (PH) Dissertation, Department of Sanitary Engineering, All India Institute of Hygiene \& Public Health (AIIH \& PH), Kolkata, West Bengal, India. 2006.

[87] Dong H, Guan X, Lo IM. Fate of As (V)-treated nano zero-valent iron: determination of arsenic desorption potential under varying environmental conditions by phosphate extraction. Water Research. 2012; 46(13):4071-80.

[88] Di Natale F, Erto A, Lancia A. Desorption of arsenic from exhaust activated carbons used for water purification. Journal of Hazardous Materials. 2013; 260:451-8.

[89] Sanchez F, Garrabrants AC, Vandecasteele C, Moszkowicz P, Kosson DS. Environmental assessment of waste matrices contaminated with arsenic. Journal of Hazardous Materials. 2003; 96(2-3):229-57.

[90] Kumar PR, Chaudhari S, Khilar KC, Mahajan SP. Removal of arsenic from water by electrocoagulation. Chemosphere. 2004; 55(9):1245-52.

[91] Lakshmipathiraj P, Prabhakar S, Raju GB. Studies on the electrochemical decontamination of wastewater containing arsenic. Separation and Purification Technology. 2010; 73(2):114-21.

[92] García-lara AM, Montero-ocampo C. Improvement of arsenic electro-removal from underground water by lowering the interference of other ions. Water, Air, and Soil Pollution. 2010.

[93] Amrose SE, Bandaru SR, Delaire C, Van GCM, Dutta A, Debsarkar A, et al. Electro-chemical arsenic remediation: field trials in West Bengal. Science of the Total Environment. 2014; 488:539-46. 
[94] Pantuzzo FL, Ciminelli VS. Arsenic association and stability in long-term disposed arsenic residues. Water Research. 2010; 44(19):5631-40.

[95] http://www.epa.gov/solidwaste/hazard/testmethods/sw 846/pdfs/9096.pdf. Accessed 10 May 2021.

[96] http://www.waterboards.ca.gov/rwqcb5/plans_policies /guidance/dlm.pdf. Accessed 10 May 2021.

[97] https://infostore.saiglobal.com/en-au/standards/as4439-3-2019-121781_saig_as_as_2773575/. Accessed 10 May 2021.

[98] https://cfpub.epa.gov/si/si_public_record_report.cfm? $L a b=N R M R L \&$ dirEntry $I d=63239$. Accessed 10 May 2021.

[99] Hooper K, Iskander M, Sivia G, Hussein F, Hsu J, Deguzman $\mathrm{M}$, et al. Toxicity characteristic leaching procedure fails to extract oxoanion-forming elements that are extracted by municipal solid waste leachates. Environmental Science \& Technology. 1998; 32(23):3825-30.

[100] Ghosh A, Mukiibi M, Ela W. TCLP underestimates leaching of arsenic from solid residuals under landfill conditions. Environmental Science \& Technology. 2004; 38(17):4677-82.

[101] Stuckman MY, Lenhart JJ, Walker HW. Abiotic properties of landfill leachate controlling arsenic release from drinking water adsorbents. Water Research. 2011; 45(16):4782-92.

[102] Parsons CT, Couture RM, Omoregie EO, Bardelli F, Greneche JM, Roman-ross G, et al. The impact of oscillating redox conditions: arsenic immobilisation in contaminated calcareous floodplain soils. Environmental Pollution. 2013; 178:254-63.

[103] Sullivan C, Tyrer M, Cheeseman CR, Graham NJ. Disposal of water treatment wastes containing arsenic - a review. Science of the Total Environment. 2010; 408(8):1770-8.

[104] http://www.epa.gov/osw/hazard/testmethods/sw846/p dfs/1311.pdf. Accessed 10 May 2021.

[105] http://www.epa.gov/solidwaste/hazard/testmethods/s w846/pdfs/chap7.pdf. Accessed 10 May 2021.

[106] https://www.cpcb.nic.in/GeneralStandards.pdf. Accessed 10 May 2021.

[107] http://cgwb.gov.in/documents/Bhujal_News_24_2.pd f. Accessed 10 May 2021.

[108] Han FX, Kingery WL, Selim HM, Gerard PD, Cox MS, Oldham JL. Arsenic solubility and distribution in poultry waste and long-term amended soil. Science of the Total Environment. 2004; 320(1):51-61.

[109] Rahman MA, Jalil MA, Ali MA. Transformation of arsenic in the presence of cow dung and arsenic sludge disposal and management strategy in Bangladesh. Journal of Hy drology. 2014; 518:486-92.

[110] Zhao R, Novak JT, Goldsmith CD. Treatment of organic matter and methylated arsenic in landfill biogas condensate. Waste Management. 2013; 33(5):1207-14.

[111] Akinde SB, Obire O. Aerobic heterotrophic bacteria and petroleum-utilizing bacteria from cow dung and poultry manure. World Journal of Microbiology and Biotechnology. 2008; 24:1999-2002.
[112] Mestrot A, Xie WY, Xue X, Zhu YG. Arsenic volatilization in model anaerobic biogas digesters. Applied Geochemistry. 2013; 33:294-7.

[113] Pal A, Nayak B, Das B, Hossain MA, Ahamed S, Chakraborti D. Additional danger of arsenic exposure through inhalation from burning of cow dung cakes laced with arsenic as a fuel in arsenic affected villages in Ganga-Meghna-Brahmaputra plain. Journal of Environmental Monitoring. 2007; 9(10):1067-70.

[114] Ali MA, Badruzzaman AB, Jalil MA, Ahmed MF, Kamruzzaman M, Rahman MA, et al. Fate of arsenic in wastes generated from arsenic removal units. In proceedings of BUET-UNU symposium on fate of arsenic in the environment, Dhaka 2003 (pp. 147-59).

[115] Leist M, Casey RJ, Caridi D. The management of arsenic wastes: problems and prospects. Journal of Hazardous Materials. 2000; 76(1):125-38.

[116] Mohan D, Pittman JCU. Arsenic removal from water/wastewater using adsorbents - a critical review. Journal of Hazardous Materials. 2007; 142(1-2):1-53.

[117] Delemos JL, Bostick BC, Renshaw CE, Sturup S, Feng X. Landfill-stimulated iron reduction and arsenic release at the Coakley Superfund Site (NH). Environmental Science \& Technology. 2006; 40(1):6773.

[118] Ford RG, Acree SD, Lien BK, Scheckel KG, Luxton $\mathrm{TP}$, Ross RR et al. Delineating landfill leachate discharge to an arsenic contaminated waterway. Chemosphere. 2011; 85(9):1525-37.

[119] Roy J. Economic benefits of arsenic removal from ground water - a case study from West Bengal, India. Science of the Total Environment. 2008;397(1-3):1-12.

[120] Hossain M A, Sengupta M K, Ahamed S, Rahman MM, Mondal D, Lodh D, et al. Ineffectiveness and poor reliability of arsenic removal plants in West Bengal, India. Environmental Science \& Technology. 2005; 39(11):4300-6.

[121] Sarkar S, Blaney LM, Gupta A, Ghosh D, Sengupta AK. Use of ArsenXnp, a hybrid anion exchanger, for arsenic removal in remote villages in the Indian subcontinent. Reactive and Functional Poly mers. 2007; 67(12):1599-611.

[122] Sarkar S, Blaney LM, Gupta A, Ghosh D, Sengupta AK. Arsenic removal from groundwater and its safe containment in a rural environment: validation of a sustainable approach. Environmental Science \& Technology . 2008; 42(12):4268-73.

[123] Abrajevitch A, Van DVR, Rea DK. Variations in relative abundances of goethite and hematite in Bengal fan sediments: climatic vs. diagenetic signals. Marine Geology. 2009; 267(3-4):191-206.

[124] Gupta VK, Saini VK, Jain N. Adsorption of As (III) from aqueous solutions by iron oxide-coated sand. Journal of Colloid and Interface Science. 2005; 288(1):55-60.

[125] Baig SA, Sheng T, Hu Y, Lv X, Xu X. Adsorptive removal of arsenic in saturated sand filter containing amended adsorbents. Ecological Engineering. 2013; 60:345-53. 
[126] Ghosh D, Sarkar S, Sengupta AK, Gupta A. Investigation on the long-term storage and fate of arsenic obtained as a treatment residual: a case study. Journal of Hazardous Materials. 2014; 271:302-10.

[127] Rahman IM, Begum ZA, Sawai H, Maki T, Hasegawa H. Decontamination of spent iron-oxide coated sand from filters used in arsenic removal. Chemosphere. 2013; 92(2):196-200.

[128] Chen AS, Sorg TJ, Wang L. Regeneration of ironbased adsorptive media used for removing arsenic from groundwater. Water Research. 2015; 77:85-97.

[129] Diamadopoulos E, Ioannidis S, Sakellaropoulos GP. As (V) removal from aqueous solutions by fly ash. Water Research. 1993; 27(12):1773-7.

[130] Li Y, Zhang FS, Xiu FR. Arsenic (V) removal from aqueous sy stem using adsorbent developed from a high iron-containing fly ash. Science of the Total Environment. 2009; 407(21):5780-6.

[131] Kashiwakura S, Ohno H, Matsubae-yokoyama K, Kumagai Y, Kubo H, Nagasaka T. Removal of arsenic in coal fly ash by acid washing process using dilute $\mathrm{H}_{2} \mathrm{SO}_{4}$ solvent. Journal of Hazardous Materials. 2010; 181(1-3):419-25.

[132] Sushil S, Batra VS. Analysis of fly ash heavy metal content and disposal in three thermal power plants in India. Fuel. 2006; 85(17-18):2676-9.

[133] Pandey VC, Singh JS, Singh RP, Singh N, Yunus M. Arsenic hazards in coal fly ash and its fate in Indian scenario. Resources, Conservation and Recycling. 2011; 55(9-10):819-35.

[134] Leist M, Casey RJ, Caridi D. The fixation and leaching of cement stabilized arsenic. Waste Management. 2003; 23(4):353-9.

[135] Kundu S, Kavalakatt SS, Pal A, Ghosh SK, M andal M, Pal T. Removal of arsenic using hardened paste of Portland cement: batch adsorption and column study. Water Research. 2004; 38(17):3780-90.

[136] Paria S, Yuet PK. Solidification-stabilization of organic and inorganic contaminants using portland cement: a literature review. Environmental Reviews. 2006; 14(4):217-55.

[137] Banerjee G, Chakraborty R. Management of arsenicladen water plant sludge by stabilization. Clean Technologies and Environmental Policy. 2005; 7:2708.

[138] Radovanović DĐ, Kamberović ŽJ, Korać MS, Rogan JR. Solidified structure and leaching properties of metallurgical wastewater treatment sludge after solidification/stabilization process. Journal of Environmental Science and Health, Part A. 2016; 51(1):34-43.

[139] Roy A, Van GCM, Mookherjee I, Debsarkar A, Dutta A. Concrete stabilization of arsenic-bearing iron sludge generated from an electrochemical arsenic remediation plant. Journal of Environmental Management. 2019; 233:141-50.
[140] Garrabrants AC, Sanchez F, Kosson DS. Changes in constituent equilibrium leaching and pore water characteristics of a Portland cement mortar as a result of carbonation. Waste Management. 2004; 24(1):19-36.

[141] Singh TS, Pant KK. Solidification/stabilization of arsenic containing solid wastes using portland cement, fly ash and polymeric materials. Journal of Hazardous M aterials. 2006; 131(1-3):29-36.

[142] Kundu S, Gupta AK. Immobilization and leaching characteristics of arsenic from cement and/or lime solidified/stabilized spent adsorbent containing arsenic. Journal of Hazardous Materials. 2008; 153(1-2):43443.

[143] Xu H, Min X, Wang Y, Ke Y, Yao L, Liu D et al. Stabilization of arsenic sulfide sludge by hydrothermal treatment. Hy drometallurgy. 2020.

[144] Dzombak DA, Morel FM. Surface complexation modeling: hydrous ferric oxide. John Wiley \& Sons; 1990.

[145] Rathore VK, Mondal P. Stabilization of arsenic and fluoride bearing spent adsorbent in clay bricks: preparation, characterization and leaching studies. Journal of Environmental Management. 2017;200:1609.

[146] Rouf MA. Effects of using arsenic-iron sludge in brick making.2003.

[147] Mahzuz HM, Alam R, Alam MN, Basak R, Islam MS. Use of arsenic contaminated sludge in making ornamental bricks. International Journal of Environmental Science and Technology. 2009; 6(22):291-8.

[148] Hassan KM, Fukushi K, Turikuzzaman K, Moniruzzaman SM. Effects of using arsenic-iron sludge wastes in brick making. Waste Management. 2014; 34(6):1072-8.

[149] Schacht C. Refractories handbook. CRC Press; 2004.

[150] Sadik C, El AIE, Albizane A. Recent advances in silica-alumina refractory: a review. Journal of Asian Ceramic Societies. 2014; 2(2):83-96.

[151] Bacevic J. Unthinking knowledge production: from post-COVID to post-carbon futures. Globalizations. 2020:1-3.

[152] Koley S. Challenges in sustainable development of smart cities in India. Sustainability: The Journal of Record. 2020; 13(4):155-60.

[153] Mofijur M, Fattah IR, Alam MA, Islam AS, OngHC, Rahman SA, et al. Impact of COVID-19 on the social, economic, environmental and energy domains: lessons learnt from a global pandemic. Sustainable Production and Consumption. 2020; 26: 343-59.

[154] Koley S. Briefing: grim future of work and labour after the 2020 pandemic, with reference to India. In Proceedings of the Institution of Civil EngineersEngineering Sustainability 2021; 174(2):55-7. Thomas Telford Ltd. 


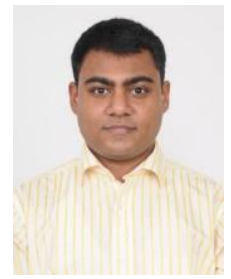

Soumyajit Koley has been a Consultant for the Water Quality Monitoring and Surveillance Programme of the Government of West Bengal in India. His research expertise lies in formulating sustainable resource management policies as effective mitigation strategies to combat climate change and outbreaks of infectious diseases. He earned a Bachelor of Technology degree in Civil Engineering in the year 2012, from the esteemed Hooghly Engineering \& Technology College (affiliated to West Bengal University of Technology) of the state of West Bengal. Subsequently, in the year 2014, he also attained a Master of Technology degree in Civil Engineering (specialization: Engineering Geosciences) from the prestigious Indian Institute of Technology, Kanpur of India. He is an avid reader of Open Access publications and believes that scientific knowledge should be accessible by anyone desirous of achieving academic glory and wisdom. As a nationalist, he wishes to see India become self-reliant in international scholarly publishing, in the coming decades.

Email: samkoley5@gmail.com

\begin{tabular}{|c|c|c|}
\hline ppen & & \\
\hline S.No. & Abbre viation & Description \\
\hline 1 & AA & Activated Alumina \\
\hline 2 & $\mathrm{AE}$ & ANIR Engineering \\
\hline 3 & AIIH \& PH & $\begin{array}{l}\text { All India Institute of Hygiene \& } \\
\text { Public Health }\end{array}$ \\
\hline 4 & ARP & Arsenic Removal Plant \\
\hline 5 & ARU & Arsenic Removal Unit \\
\hline 6 & ATU & Arsenic Treatment Unit \\
\hline 7 & BESU & $\begin{array}{l}\text { Bengal Engineering and Science } \\
\text { University }\end{array}$ \\
\hline 8 & CGCRI & $\begin{array}{l}\text { Central Glass and Ceramic Research } \\
\text { Institute }\end{array}$ \\
\hline 9 & CWR & Clear Water Reservoir \\
\hline 10 & EDT A & Ethylene Diamine T etra-AceticAcid \\
\hline 11 & EPT ox & $\begin{array}{l}\text { Extraction Procedure ToxicityTest } \\
\text { Method }\end{array}$ \\
\hline 12 & GFH & Granular Ferric Hydroxide \\
\hline 13 & GMB & Ganga-Meghna-Brahmaputra \\
\hline 14 & GP & Gram Panchayat \\
\hline 15 & INR & Indian Rupee \\
\hline 16 & ITP GmbH & $\begin{array}{l}\text { It is a private company based in } \\
\text { Germany, that manufactures } \\
\text { industrial goods and equipment }\end{array}$ \\
\hline 17 & NGO & Non-Governmental Organization \\
\hline 18 & O\&M & Operation and Maintenance \\
\hline 19 & PET & Polyethylene Terephthalate \\
\hline 20 & PHED & $\begin{array}{l}\text { Public Health } \text { Engineering } \\
\text { Department }\end{array}$ \\
\hline 21 & PWS & Piped-Water-Supply Schemes \\
\hline 22 & SDG & Sustainable Development Goals \\
\hline 23 & SFH & Slurry Ferric Hydroxide \\
\hline 24 & TCLP & $\begin{array}{l}\text { Toxicity Characteristic Leaching } \\
\text { Procedure }\end{array}$ \\
\hline 25 & UNICEF & $\begin{array}{l}\text { United Nations } \quad \text { Children's } \\
\text { Emergency Fund }\end{array}$ \\
\hline 26 & USD & United States Dollar \\
\hline 27 & USEPA & $\begin{array}{l}\text { United States Environmental } \\
\text { Protection Agency }\end{array}$ \\
\hline 28 & WDXRF & $\begin{array}{lll}\text { Wavelength } & \text { Dispersive } & \text { X-ray } \\
\text { Fluorescence } & & \\
\end{array}$ \\
\hline 29 & WHO & World Health Organization \\
\hline
\end{tabular}

